\title{
In situ construction of surface defects of carbon- doped ternary cobalt-nickel-iron phosphide nanocubes for efficient overall water splitting
}

\author{
Wen-Kun Gao ${ }^{1}$, Min Yang ${ }^{1}$, Jing-Qi Chi ${ }^{1}$, Xin-Yu Zhang ${ }^{1}$, Jing-Yi Xie ${ }^{1}$, Bao-Yu Guo ${ }^{1}$, Lei Wang ${ }^{2}$, \\ Yong-Ming Chai ${ }^{1}$ and Bin Dong ${ }^{1 *}$
}

\begin{abstract}
The ternary cobalt-nickel-iron phosphide nanocubes $\left(\mathrm{P}-\mathrm{Co}_{0.9} \mathrm{Ni}_{0.9} \mathrm{Fe}_{1.2} \mathrm{NCs}\right)$ with high intrinsic activity, conductivity, defect concentration and optimized ratio have been realized through a facile phosphorization treatment using ternary cobalt-nickel-iron nanocubes of Prussian blue analogs (PBA) as a precursor. The scanning electron microscopy and transmission electron microscopy results show that the $\mathrm{P}-\mathrm{Co}_{0.9} \mathrm{Ni}_{0.9} \mathrm{Fe}_{1.2} \mathrm{NCs}$ maintain a cubic structure with a rough surface, implying the rich surface defects as exposed active sites. The thermal phosphorization of the ternary PBA precursor not only provids carbon doping but also leads to the in situ construction of surface defects on the NCs. The carbon doping from the PBA precursor lowers the charge transfer resistance and optimizes the electronic transformation. The synergistic effect among the ternary metal ions and rich defects contributes to the enhanced electrocatalytic performance. The $\mathrm{P}-\mathrm{Co}_{0.9} \mathrm{Ni}_{0.9} \mathrm{Fe}_{1.2} \mathrm{NCs}$ achieve low overpotentials of -200.7 and $273.1 \mathrm{mV}$ at a current density of $10 \mathrm{~mA} \mathrm{~cm}^{-2}$ for the hydrogen evolution reaction and the oxygen evolution reaction, respectively. The potential of overall water splitting reaches $1.52 \mathrm{~V}$ at a current density of $10 \mathrm{~mA} \mathrm{~cm}$. The longterm stability of the electrocatalysts was also evaluated. This work provides a facile method to design efficient transitionmetal-based bifunctional electrocatalysts for overall water splitting.
\end{abstract}

Keywords: in situ, surface defect, ternary metal phosphides, nanocubes, water splitting

\section{INTRODUCTION}

Exploring an efficient and applicable technology for hy- drogen generation to replace traditional fossil fuels is vitally important to relieve the energy crisis and environmental pollution [1-5]. Electrolytic water splitting can be divided into two half-reactions: the hydrogen evolution reaction (HER) and the oxygen evolution reaction (OER). Water splitting is an important strategy for the conversion of renewable resources [6,7]. However, the general overpotential for electrochemical water splitting is normally larger than the theoretical value of $1.23 \mathrm{~V}$, due to the slow charge transfer rate and sluggish kinetics of both HER and OER $[8,9]$. Therefore, developing efficient electrochemical catalysts to enhance the charge transfer rate, reduce the overpotential, and boost the reaction kinetics for water electrolysis is critical [10]. At present, Pt-based catalysts, which exhibit substantial catalytic activity, are the representative benchmark catalysts for HER, and Ir- and Ru-based electrocatalysts are the benchmark catalysts for OER $[11,12]$. However, the extensive industrial implementation of these electrochemical benchmark catalysts is restricted by their scarcity and high cost $[13,14]$. Therefore, nonprecious, robust, and efficient electrochemical catalysts based on transition metals are urgently needed to enable the production of clean energy through water electrolysis [15].

Many transition-metal-based electrocatalysts, including metal oxides, metal sulfides, and metal phosphides, have been widely investigated [16-22]. Because of their remarkable catalytic activities and conductivities, transition-metal-phosphide-based electrocatalysts such as $\mathrm{NiP}$ [19,23], FeP [24,25], CoP [21,26], FeNiP [27,28], FeCoP [29], and NiCoP $[30,31]$ have been synthesized as pro-

\footnotetext{
${ }^{1}$ State Key Laboratory of Heavy Oil Processing, Institute of New Energy, China University of Petroleum (East China), Qingdao 266580, China

${ }^{2}$ Shandong Key Laboratory of Biochemical Analysis, College of Chemistry and Molecular Engineering, Qingdao University of Science and Technology, Qingdao 266042, China

* Corresponding author (email: dongbin@upc.edu.cn)
} 
mising alternatives to Pt-based catalysts for HER or OER. Notably, the doping and introduction of other metals [32] or nonmetals [33] have become a promising strategy for enhanced electrocatalytic performance. Yan et al. [34] reported that the introduction of $\mathrm{Ag}$ and $\mathrm{Fe}$ into $\mathrm{Co}_{2} \mathrm{P}$ nanospheres effectively enhanced their bifunctional catalytic activity toward water splitting. Zhang et al. [35] revealed that nitrogen-doped $\mathrm{Ni}_{5} \mathrm{P}_{4} / \mathrm{Fe}_{3} \mathrm{P}$ nanocubes (NCs) with optimized electronic properties and abundant catalytically active sites displayed high activities toward OER. Moreover, nonmetallic-doped multimetallic phosphides possess high electrocatalytic performance and diverse synergistic effects for HER and OER [36,37].

Recently, Prussian blue analogs (PBAs) with mesoporous cubic and high electronic conversion efficiency have been identified as excellent carriers for OER under alkaline conditions [38]. In most metal phosphide electrocatalysts, the phosphorus ions serve as a proton acceptor to effectively promote proton exchange and charge transfer for the evolution of both oxygen and hydrogen $[39,40]$. Therefore, developing multimetal phosphides for water electrolysis by incorporating the structural merits of PBA and a multimetal synergistic effect is an extremely promising strategy $[41,42]$.

Herein, carbon-doped ternary cobalt-nickel-iron phosphide NCs $\left(\mathrm{P}^{-} \mathrm{Co}_{0.9} \mathrm{Ni}_{0.9} \mathrm{Fe}_{1.2} \mathrm{NCs}\right)$ based on PBA were fabricated through a spontaneous coprecipitation and one-step phosphorization process. Ternary cobaltnickel-iron phosphides with different ratios of nickel and cobalt were prepared. As expected, the optimized $\mathrm{P}-\mathrm{Co}_{0.9} \mathrm{Ni}_{0.9} \mathrm{Fe}_{1.2}$ NCs with a unique structure, more abundant surface defects, and a larger specific surface area exhibited excellent electrochemical catalytic performances compared with other samples for overall water splitting. The $\mathrm{P}-\mathrm{Co}_{0.9} \mathrm{Ni}_{0.9} \mathrm{Fe}_{1.2} \mathrm{NCs}$ achieved low overpotentials of -200.7 and $273.1 \mathrm{mV}$ at a current density of $10 \mathrm{~mA} \mathrm{~cm}^{-2}$ for HER and OER, respectively. Moreover, the $\mathrm{P}-\mathrm{Co}_{0.9} \mathrm{Ni}_{0.9} \mathrm{Fe}_{1.2} \mathrm{NCs}$ for water electrolysis achieved a current density of $10 \mathrm{~mA} \mathrm{~cm}^{-2}$ at $1.52 \mathrm{~V}$, which was an improvement over the potentials reported in previous studies. The electrocatalytic activities and mechanism for $\mathrm{P}-\mathrm{Co}_{0.9} \mathrm{Ni}_{0.9} \mathrm{Fe}_{1.2} \mathrm{NCs}$ were discussed.

\section{EXPERIMENTAL SECTION}

\section{Materials and reagents}

Cobalt(II) chloride hexahydrate $\left(\mathrm{CoCl}_{2} \cdot 6 \mathrm{H}_{2} \mathrm{O}, \geq 99 \%\right)$, nickel(II) nitrate hexahydrate $\left(\mathrm{Ni}\left(\mathrm{NO}_{3}\right)_{2} \cdot 6 \mathrm{H}_{2} \mathrm{O}, \geq 99 \%\right)$, trisodium citrate dihydrate $\left(\mathrm{Na}_{3} \mathrm{C}_{6} \mathrm{H}_{5} \mathrm{O}_{7} \cdot 2 \mathrm{H}_{2} \mathrm{O}, \geq 99 \%\right)$, potassium ferricyanide $\left(\mathrm{K}_{3}\left[\mathrm{Fe}(\mathrm{CN})_{6}\right], \geq 99 \%\right)$, and sodium hypophosphite hydrate $\left(\mathrm{NaH}_{2} \mathrm{PO}_{2} \cdot \mathrm{H}_{2} \mathrm{O},>98 \%\right)$ were used as analytical-grade reagents without further purification.

\section{Synthesis of $\mathrm{Ni}_{1.8} \mathrm{Fe}_{1.2} \mathrm{NCs}$ and $\mathrm{Co}_{1.8} \mathrm{Fe}_{1.2} \mathrm{NCs}$}

$\mathrm{Ni}_{1.8} \mathrm{Fe}_{1.2}$ NCs was prepared via a modified version of a previously reported method [43]. Typically, $1.2 \mathrm{mmol}$ of $\mathrm{K}_{3}\left[\mathrm{Fe}(\mathrm{CN})_{6}\right]$ was dissolved in $60 \mathrm{~mL}$ deionized water under stirring to form homogeneous solution A. Next, $1.8 \mathrm{mmol} \mathrm{Ni}\left(\mathrm{NO}_{3}\right)_{2} \cdot 6 \mathrm{H}_{2} \mathrm{O}$ and $2.7 \mathrm{mmol} \mathrm{Na}_{3} \mathrm{C}_{6} \mathrm{H}_{5} \mathrm{O}_{7}$. $2 \mathrm{H}_{2} \mathrm{O}$ were dissolved in $60 \mathrm{~mL}$ deionized water under stirring to form homogeneous solution B. Solution A was then dropped into solution $B$ to form a homogeneous solution. After the solution was vigorously magnetically stirred at room temperature, it was spontaneously aged for $48 \mathrm{~h}$ at $25^{\circ} \mathrm{C}$. The obtained precipitate was collected by centrifugation, washed with ethanol for several times, and dried under vacuum. $\mathrm{Co}_{1.8} \mathrm{Fe}_{1.2} \mathrm{NCs}$ were synthesized using the same process used to prepare $\mathrm{Ni}_{1.8} \mathrm{Fe}_{1.2} \mathrm{NCs}$ except that $\mathrm{Ni}\left(\mathrm{NO}_{3}\right)_{2} \cdot 6 \mathrm{H}_{2} \mathrm{O}$ was replaced with $\mathrm{CoCl}_{2}$. $6 \mathrm{H}_{2} \mathrm{O}$.

\section{Synthesis of $\mathrm{Co}_{0.9} \mathrm{Ni}_{0.9} \mathrm{Fe}_{1.2} \mathrm{NCs}, \mathrm{Co}_{1.2} \mathrm{Ni}_{0.6} \mathrm{Fe}_{1.2} \mathrm{NCs}$, and $\mathrm{Co}_{0.6} \mathrm{Ni}_{1.2} \mathrm{Fe}_{1.2} \mathrm{NCs}$}

For the $\mathrm{Co}_{0.9} \mathrm{Ni}_{0.9} \mathrm{Fe}_{1.2} \mathrm{NCs}, 0.9 \mathrm{mmol} \mathrm{Ni}\left(\mathrm{NO}_{3}\right)_{2} \cdot 6 \mathrm{H}_{2} \mathrm{O}$, $0.9 \mathrm{mmol} \mathrm{CoCl} \cdot 6 \mathrm{H}_{2} \mathrm{O}$, and $2.7 \mathrm{mmol} \mathrm{Na} \mathrm{C}_{6} \mathrm{H}_{5} \mathrm{O}_{7} \cdot 2 \mathrm{H}_{2} \mathrm{O}$ were dissolved in $60 \mathrm{~mL}$ deionized water to form solution C; then solution A was dropped into solution C to form a homogeneous solution. The following synthesis conditions were similar to those used to prepare the $\mathrm{Ni}_{1.8} \mathrm{Fe}_{1.2}$ NCs. To synthesize the $\mathrm{Co}_{1.2} \mathrm{Ni}_{0.6} \mathrm{Fe}_{1.2} \mathrm{NCs}$ and $\mathrm{Co}_{0.6} \mathrm{Ni}_{1.2} \mathrm{Fe}_{1.2} \mathrm{NCs}, \mathrm{CoCl}_{2} \cdot 6 \mathrm{H}_{2} \mathrm{O}$ and $\mathrm{Ni}\left(\mathrm{NO}_{3}\right)_{2} \cdot 6 \mathrm{H}_{2} \mathrm{O}$ with a molar ratio of 2:1 and 1:2 were used to form solution $\mathrm{C}$; the other conditions were similar to those used to prepare the $\mathrm{Co}_{0.9} \mathrm{Ni}_{0.9} \mathrm{Fe}_{1.2} \mathrm{NCs}$.

\section{Synthesis of $\mathrm{P}-\mathrm{Ni}_{1.8} \mathrm{Fe}_{1.2}$ NCs and $\mathrm{P}-\mathrm{Co}_{1.8} \mathrm{Fe}_{1.2}$ NCs}

$\mathrm{P}-\mathrm{Ni}_{1.8} \mathrm{Fe}_{1.2}$ NCs were synthesized through high-temperature phosphorization. In a typical process, the obtained $\mathrm{Ni}_{1.8} \mathrm{Fe}_{1.2} \mathrm{NCs}(0.05 \mathrm{~g})$ and $\mathrm{NaH}_{2} \mathrm{PO}_{2} \cdot \mathrm{H}_{2} \mathrm{O}(0.6 \mathrm{~g})$ were placed in a porcelain boat and loaded at two independent locations with $\mathrm{Ni}_{1.8} \mathrm{Fe}_{1.2} \mathrm{NCs}$ at the downstream side of a tube furnace. The phosphorization process was carried out under an argon atmosphere $\left(0.5 \mathrm{~mL} \mathrm{~s}^{-1}, 99.99 \%\right)$ and the tube furnace was heated to $350^{\circ} \mathrm{C}$ at a rate of $2^{\circ} \mathrm{C} \mathrm{min}^{-1}$ and maintained at this temperature for $2 \mathrm{~h}$. The $\mathrm{P}-\mathrm{Ni}_{1.8} \mathrm{Fe}_{1.2}$ NCs were subsequently collected after the sample cooled to room temperature. Using $\mathrm{Co}_{1.8} \mathrm{Fe}_{1.2} \mathrm{NCs}$ as the precursor, we synthesized the $\mathrm{P}-\mathrm{Co}_{1.8} \mathrm{Fe}_{1.2}$ NCs via the same thermal phosphorization procedure. 
Synthesis of P-Co ${ }_{0.9} \mathrm{Ni}_{0.9} \mathrm{Fe}_{1.2} \mathrm{NCs}, \mathrm{P}-\mathrm{Co}_{1.2} \mathrm{Ni}_{0.6} \mathrm{Fe}_{1.2} \mathrm{NCs}$, and P-Co . $_{0.6} \mathrm{Ni}_{1.2} \mathrm{Fe}_{1.2} \mathrm{NCs}$

The syntheses of the $\mathrm{P}-\mathrm{Co}_{0.9} \mathrm{Ni}_{0.9} \mathrm{Fe}_{1.2} \quad \mathrm{NCs}$, $\mathrm{P}-\mathrm{Co}_{1.2} \mathrm{Ni}_{0.6} \mathrm{Fe}_{1.2} \mathrm{NCs}$, and the $\mathrm{P}-\mathrm{Co}_{0.6} \mathrm{Ni}_{1.2} \mathrm{Fe}_{1.2}$ NCs were similar to those of the $\mathrm{P}-\mathrm{Ni}_{1.8} \mathrm{Fe}_{1.2} \mathrm{NCs}$, except that the $\mathrm{Co}_{0.9} \mathrm{Ni}_{0.9} \mathrm{Fe}_{1.2}$ NCs, $\mathrm{Co}_{1.2} \mathrm{Ni}_{0.6} \mathrm{Fe}_{1.2} \mathrm{NCs}$, and $\mathrm{Co}_{0.6} \mathrm{Ni}_{1.2} \mathrm{Fe}_{1.2}$ NCs were substituted for the $\mathrm{Ni}_{1.8} \mathrm{Fe}_{1.2} \mathrm{NCs}$ as the precursor, respectively.

\section{Characterizations}

X-ray powder diffraction (XRD, X'Pert PRO MPD, Cu $\mathrm{Ka}$ ) patterns were collected to explore the crystal structures of the samples; the scanning range was from $5^{\circ}$ to $90^{\circ}$, and the scanning rate was $10^{\circ} \mathrm{min}^{-1}$. X-ray photoelectron spectroscopy (XPS, VG ESCALABMK II photoelectron spectrometer, $\mathrm{Al} \mathrm{Ka}, 1,486.6 \mathrm{eV}$ ) was used to analyze the valence states of the major elements. Scanning electron microscopy (SEM, S-4800, Hitachi), transmission electron microscopy (TEM), and high-resolution TEM (HRTEM, FEI Tecnai $G^{2}$ ) were used to explore the structure and morphology of the obtained samples. Energy-dispersive X-ray (EDX) analysis and SEM mapping were used to identify the presence and distribution of the predominant elements. $\mathrm{N}_{2}$ adsorption-desorption isotherms were used to investigate the Brunauer-EmmettTeller (BET) surface areas and porosity of the $\mathrm{P}-\mathrm{Co}_{0.9^{-}}$ $\mathrm{Ni}_{0.9} \mathrm{Fe}_{1.2} \mathrm{NCs}$ and $\mathrm{Co}_{0.9} \mathrm{Ni}_{0.9} \mathrm{Fe}_{1.2} \mathrm{NCs}$ at $77 \mathrm{~K}$.

\section{Electrochemical measurements}

Electrochemical measurements of the samples were conducted at room temperature in $1.0 \mathrm{~mol} \mathrm{~L}^{-1} \mathrm{KOH}$ solution with Gamry Reference 600 electrochemical equipment. OER and HER electrocatalytic performances were explored in a three-electrode cell with $1.0 \mathrm{~mol} \mathrm{~L}^{-1} \mathrm{KOH}$ solution as the electrolyte. The auxiliary electrode was a Pt plate $(1 \mathrm{~cm} \times 1 \mathrm{~cm})$ for OER or a graphite rod for HER, and a saturated calomel electrode (SCE) was used as the reference electrode. Samples deposited onto the surface of glassy carbon electrodes (GCEs, diameter of $4 \mathrm{~mm}$ ) were used as the working electrode. Typically, $5 \mathrm{mg}$ catalyst was dispersed in $1 \mathrm{~mL}$ mixed solution of Nafion and absolute ethanol. After $30 \mathrm{~min}$ ultrasonic dispersion, $5 \mu \mathrm{L}$ of the obtained suspensions were dropped onto the GCE and then dried at $30^{\circ} \mathrm{C}$ (approximate loading: $0.2 \mathrm{mg} \mathrm{cm}^{-2}$ ). The electrolyte solution was saturated with $\mathrm{O}_{2}$ or $\mathrm{N}_{2}$ for OER or HER, respectively. Linear sweep voltammetry (LSV) curves were recorded out from 0 to $0.7 \mathrm{~V}(v s$. SCE) and from -1 to $-1.7 \mathrm{~V}(v s$. SCE) at a common scan rate of $5 \mathrm{mV} \mathrm{s}^{-1}$ for OER and HER, respectively. Electrochemical impedance spectroscopy (EIS) was undertaken at 0.48 and $-1.36 \mathrm{~V}$ (vs. SCE) in the frequency range from $0.1 \mathrm{~Hz}$ to $100 \mathrm{kHz}$ with an alternating current potential amplitude of $5 \mathrm{mV}$. The electrochemical double-layer capacitance $\left(C_{\mathrm{dl}}\right)$ was determined from cyclic voltammograms recorded from 0.1 to $0.2 \mathrm{~V}$ ( vs. SCE) and from -0.45 to $-0.55 \mathrm{~V}$ (vs. SCE) at various scan rates for OER and HER, respectively. The electrochemical stability tests of the $\mathrm{P}-\mathrm{Co}_{0.9} \mathrm{Ni}_{0.9} \mathrm{Fe}_{1.2} \mathrm{NCs}$ were conducted through cyclic voltammetry (CV) for 1,000 cycles at a scan rate of $100 \mathrm{mV} \mathrm{s}^{-1}$ or through chronoamperometry at $0.45 \mathrm{~V}$ ( $v s$. SCE) for OER and $-1.27 \mathrm{~V}$ ( $v s$. SCE) for HER. The overall water splitting was conducted in a three-electrode system using $\mathrm{P}-\mathrm{Co}_{0.9^{-}}$ $\mathrm{Ni}_{0.9} \mathrm{Fe}_{1.2} \mathrm{NCs}$, and the LSV curves were recorded at a scan rate of $5 \mathrm{mV} \mathrm{s}^{-1}$.

All of the potential values were calibrated with a reversible hydrogen electrode (RHE). The potential conversions for the SCE and the RHE were based on following equation [44]:

$E(v s . \mathrm{RHE})=E(v s . \mathrm{SCE})+0.059 \mathrm{pH}+0.244 \mathrm{~V}=E(v s$. SCE) +1.07 V. (1)

\section{RESULTS AND DISCUSSION}

The formation process of $\mathrm{P}-\mathrm{Co}_{0.9} \mathrm{Ni}_{0.9} \mathrm{Fe}_{1.2} \mathrm{NCs}$ with surface defects is systematically presented in Scheme 1. First, $\mathrm{Co}_{0.9} \mathrm{Ni}_{0.9} \mathrm{Fe}_{1.2} \mathrm{NCs}, \mathrm{Co}_{1.2} \mathrm{Ni}_{0.6} \mathrm{Fe}_{1.2} \mathrm{NCs}$, and $\mathrm{Co}_{0.6^{-}}$ $\mathrm{Ni}_{1.2} \mathrm{Fe}_{1.2}$ NCs were synthesized as precursors via the liquid-phase synthesis process. Second, the $\mathrm{P}-\mathrm{Co}_{0.9} \mathrm{Ni}_{0.9} \mathrm{Fe}_{1.2}$ NCs, $\mathrm{P}-\mathrm{Co}_{1.2} \mathrm{Ni}_{0.6} \mathrm{Fe}_{1.2}$ NCs, and $\mathrm{P}-\mathrm{Co}_{0.6} \mathrm{Ni}_{1.2} \mathrm{Fe}_{1.2} \quad \mathrm{NCs}$ were prepared through phosphorization at high temperature. The formation route of $\mathrm{P}-\mathrm{Co}_{0.9} \mathrm{Ni}_{0.9} \mathrm{Fe}_{1.2} \mathrm{NCs}$ can be expressed as follows:

$3 \mathrm{CoCl}_{2} \cdot 6 \mathrm{H}_{2} \mathrm{O}+3 \mathrm{Ni}\left(\mathrm{NO}_{3}\right)_{2} \cdot 6 \mathrm{H}_{2} \mathrm{O}+4 \mathrm{~K}_{3}\left[\mathrm{Fe}(\mathrm{CN})_{6}\right] \rightarrow$ $\mathrm{Co}_{3}\left[\mathrm{Fe}(\mathrm{CN})_{6}\right]_{2} \cdot \mathrm{H}_{2} \mathrm{O}+\mathrm{Ni}_{3}\left[\mathrm{Fe}(\mathrm{CN})_{6}\right]_{2} \cdot \mathrm{H}_{2} \mathrm{O}+6 \mathrm{KNO}_{3}+$ $6 \mathrm{KCl}+34 \mathrm{H}_{2} \mathrm{O}$,

$4 \mathrm{Co}_{3}\left[\mathrm{Fe}(\mathrm{CN})_{6}\right]_{2} \cdot \mathrm{H}_{2} \mathrm{O}+4 \mathrm{Ni}_{3}\left[\mathrm{Fe}(\mathrm{CN})_{6}\right]_{2} \cdot \mathrm{H}_{2} \mathrm{O}+$ $100 \mathrm{NaH}_{2} \mathrm{PO}_{2} \cdot \mathrm{H}_{2} \mathrm{O} \rightarrow 12 \mathrm{NiP}_{2}+16 \mathrm{FeP}_{4}+12 \mathrm{CoP}+$ $96 \mathrm{NaCN}+4 \mathrm{NaOH}+49 \mathrm{O}_{2}+206 \mathrm{H}_{2} \mathrm{O}$.

The $\mathrm{P}-\mathrm{Co}_{0.9} \mathrm{Ni}_{0.9} \mathrm{Fe}_{1.2} \mathrm{NCs}$ maintain the NC structure of their precursor and provide additional surface defects, which implies that they could exhibit enhanced activity for water splitting.

All of the obtained samples were characterized by XRD. As depicted in Fig. 1a, the diffraction peaks of the $\mathrm{Co}_{1.8} \mathrm{Fe}_{1.2} \mathrm{NCs}$ and the $\mathrm{Ni}_{1.8} \mathrm{Fe}_{1.2}$ NCs were well assigned to the $\mathrm{Co}_{3}\left[\mathrm{Fe}(\mathrm{CN})_{6}\right]_{2} \cdot \mathrm{H}_{2} \mathrm{O}$ phase (PDF No. 01-082-2284) and the $\mathrm{Ni}_{3}\left[\mathrm{Fe}(\mathrm{CN})_{6}\right]_{2} \cdot \mathrm{H}_{2} \mathrm{O}$ phase (PDF No. 01-082$2283)$, respectively. The pattern of the $\mathrm{Co}_{0.9} \mathrm{Ni}_{0.9} \mathrm{Fe}_{1.2} \mathrm{NCs}$ coincides well with the standard patterns of $\mathrm{Co}_{3}[\mathrm{Fe}-$ $\left.(\mathrm{CN})_{6}\right]_{2} \cdot \mathrm{H}_{2} \mathrm{O}$ (PDF No. 01-082-2284) and $\mathrm{Ni}_{3}\left[\mathrm{Fe}(\mathrm{CN})_{6}\right]_{2}$. 


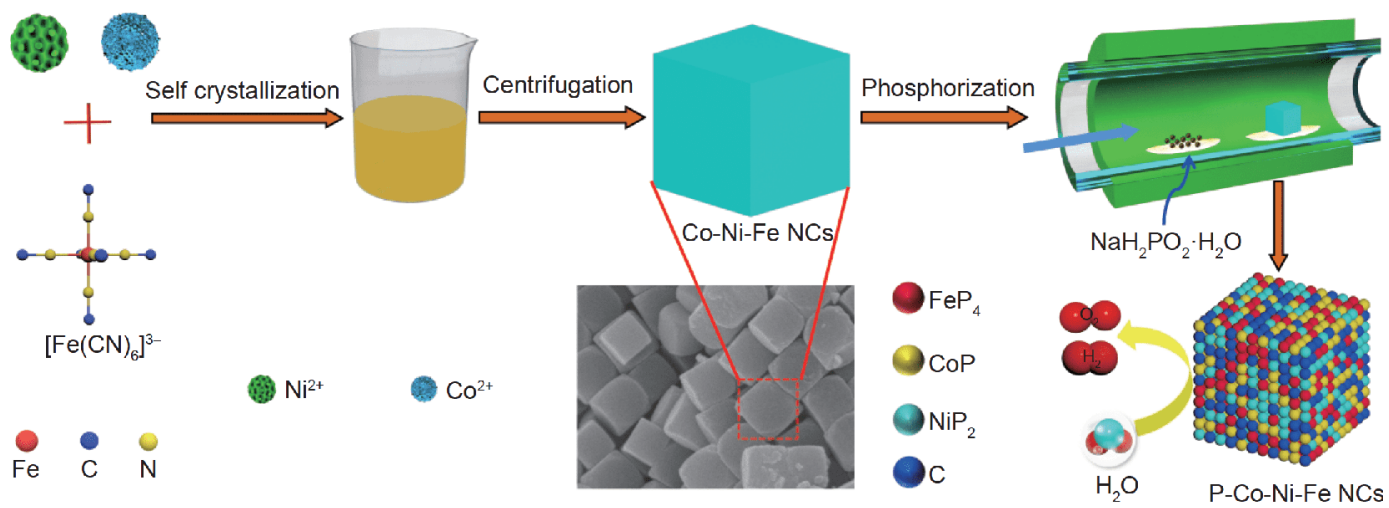

Scheme 1 Schematic of consecutive processes for synthesizing ternary metal phosphides of $\mathrm{P}-\mathrm{Co}_{0.9} \mathrm{Ni}_{0.9} \mathrm{Fe}_{1.2} \mathrm{NCs}$.
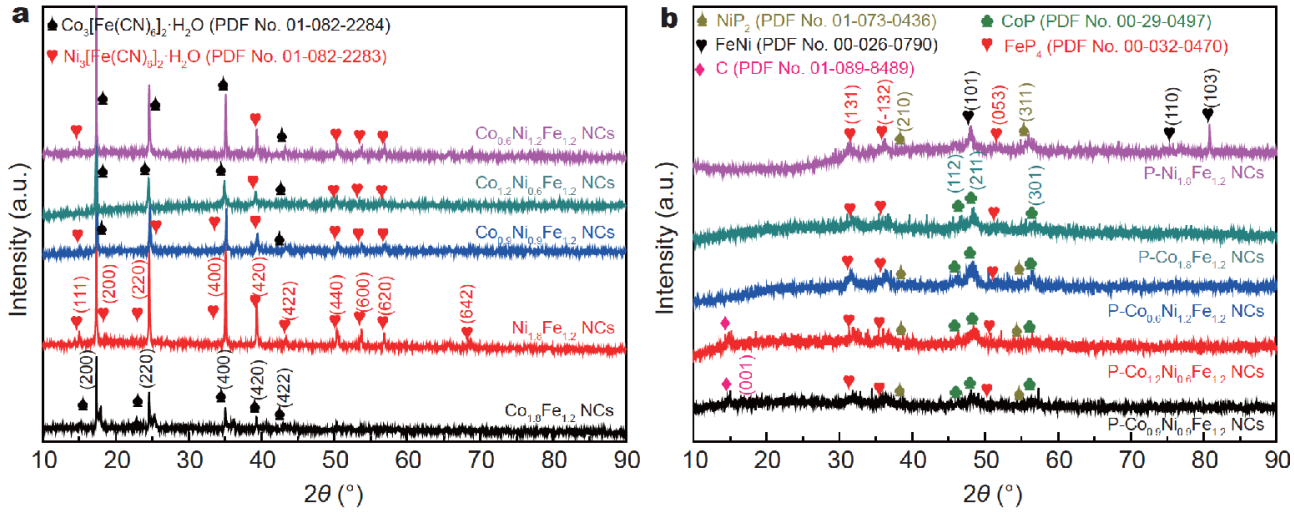

Figure 1 XRD patterns: (a) $\mathrm{Ni}_{1.8} \mathrm{Fe}_{1.2} \mathrm{NCs}, \mathrm{Co}_{1.8} \mathrm{Fe}_{1.2} \mathrm{NCs}, \mathrm{Co}_{0.9} \mathrm{Ni}_{0.9} \mathrm{Fe}_{1.2} \mathrm{NCs}, \mathrm{Co}_{1.2} \mathrm{Ni}_{0.6} \mathrm{Fe}_{1.2} \mathrm{NCs}$, and $\mathrm{Co}_{0.6} \mathrm{Ni}_{1.2} \mathrm{Fe}_{1.2} \mathrm{NCs}$; (b) P-Ni $\mathrm{Ni}_{1.8} \mathrm{Fe}_{1.2} \mathrm{NCs}$, P-Co ${ }_{1.8} \mathrm{Fe}_{1.2}$ NCs, P-Co ${ }_{0.9} \mathrm{Ni}_{0.9} \mathrm{Fe}_{1.2}$ NCs, P-Co $\mathrm{Co}_{1.2} \mathrm{Ni}_{0.6} \mathrm{Fe}_{1.2} \mathrm{NCs}$, and P-Co $\mathrm{Co}_{0.6} \mathrm{Ni}_{1.2} \mathrm{Fe}_{1.2}$ NCs.

$\mathrm{H}_{2} \mathrm{O}$ (PDF No. 01-082-2283), implying good crystallinity. The diffraction peaks of the $\mathrm{Co}_{1.2} \mathrm{Ni}_{0.6} \mathrm{Fe}_{1.2} \mathrm{NCs}$ and the $\mathrm{Co}_{0.6} \mathrm{Ni}_{1.2} \mathrm{Fe}_{1.2} \mathrm{NCs}$ in Fig. 1a can be indexed to the standard patterns of $\mathrm{Co}_{3}\left[\mathrm{Fe}(\mathrm{CN})_{6}\right]_{2} \cdot \mathrm{H}_{2} \mathrm{O}$ (PDF No. 01082-2284) and $\mathrm{Ni}_{3}\left[\mathrm{Fe}(\mathrm{CN})_{6}\right]_{2} \cdot \mathrm{H}_{2} \mathrm{O}$ (PDF No. 01-0822283). After thermal phosphorization treatment, all of the peaks in the diffraction pattern of the $\mathrm{P}-\mathrm{Co}_{0.9} \mathrm{Ni}_{0.9} \mathrm{Fe}_{1.2}$ NCs in Fig. $1 \mathrm{~b}$ are well attributed to cubic $\mathrm{NiP}_{2}$ (PDF No. 01-073-0436), CoP (PDF No. 00-029-0497), $\mathrm{FeP}_{4}$ (PDF No. 00-032-0470), and C (PDF No. 01-089-8489). Specifically, the sharp peaks of $\mathrm{NiP}_{2}$ at $37.7^{\circ}$ and $55.6^{\circ}$ are indexed to the (210) and (311) planes, respectively. The diffraction peaks at $46.2^{\circ}, 48.1^{\circ}$, and $56.8^{\circ}$ are assigned to the (112), (211), and (301) crystallographic planes, consistent with $\mathrm{CoP}$. The three observable peaks at $32.3^{\circ}$, $35.5^{\circ}$, and $52.1^{\circ}$ correspond to $\mathrm{FeP}_{4}(131),(-132)$, and (053) lattice planes, respectively. A broad peak at approximately $14.9^{\circ}$ in the patterns of the $\mathrm{P}-\mathrm{Co}_{0.9} \mathrm{Ni}_{0.9} \mathrm{Fe}_{1.2}$ NCs and $\mathrm{P}-\mathrm{Co}_{1.2} \mathrm{Ni}_{0.6} \mathrm{Fe}_{1.2} \mathrm{NCs}$ indicates the coexistence of the (001) phase of $\mathrm{C}$, possibly originating from the thermal carbonization under an Ar atmosphere. When the $\mathrm{Co}$ and $\mathrm{Ni}$ contents are varied, the intensities of these peaks change. After the phosphorization process, the intensities of the peaks associated with $\mathrm{NiP}_{2}$ in the pattern of the $\mathrm{P}-\mathrm{Co}_{0.6} \mathrm{Ni}_{1.2} \mathrm{Fe}_{1.2} \mathrm{NCs}$ are higher than the intensities of the corresponding peaks in the patterns of the $\mathrm{P}-\mathrm{Co}_{0.9} \mathrm{Ni}_{0.9} \mathrm{Fe}_{1.2}$ NCs and $\mathrm{P}-\mathrm{Co}_{1.2} \mathrm{Ni}_{0.6} \mathrm{Fe}_{1.2}$ NCs. The characteristic peaks of $\mathrm{CoP}$ in the pattern of the $\mathrm{P}^{-} \mathrm{Co}_{1.2^{-}}$ $\mathrm{Ni}_{0.6} \mathrm{Fe}_{1.2} \mathrm{NCs}$ are stronger than those in the patterns of the $\mathrm{P}-\mathrm{Co}_{0.6} \mathrm{Ni}_{1.2} \mathrm{Fe}_{1.2} \mathrm{NCs}$ and $\mathrm{P}-\mathrm{Co}_{0.9} \mathrm{Ni}_{0.9} \mathrm{Fe}_{1.2} \mathrm{NCs}$, suggesting that different elemental contents of the precursors can affect the intensity of different species. After the phosphorization at $350^{\circ} \mathrm{C}$, the intensities of the $\mathrm{FeP}_{4}$ and CoP peaks in the pattern of the $\mathrm{P}-\mathrm{Co}_{1.8} \mathrm{Fe}_{1.2} \mathrm{NCs}$ increase slightly and no other obvious peaks emerge. In the pat-

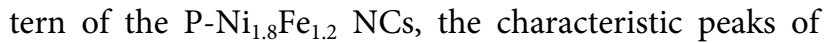
$\mathrm{FeP}_{4}$ and $\mathrm{NiP}_{2}$ are less intense, whereas peaks emerge at $48.6^{\circ}, 75.3^{\circ}$, and $84.1^{\circ}$, which correspond to the (101), (110), and (103) planes of NiFe (PDF No. 00-026-0790), respectively, indicating incomplete phosphorization of 
this sample.

XPS was used to further investigate the surface elemental states and electronic structure of the C-doped P- $\mathrm{Co}_{0.9} \mathrm{Ni}_{0.9} \mathrm{Fe}_{1.2} \mathrm{NCs}$, as shown in Fig. 2. The XPS survey scan in Fig. 2a reveals the existence of Fe, Co, Ni, P, C, N, and $\mathrm{O}$ in the $\mathrm{P}_{-} \mathrm{Co}_{0.9} \mathrm{Ni}_{0.9} \mathrm{Fe}_{1.2}$ NCs. The observed N originates from $\mathrm{CN}^{-}$, and the $\mathrm{O}$ originates from adsorbed $\mathrm{H}_{2} \mathrm{O}$ or $\mathrm{O}_{2}$ as a result of exposure of the catalyst to air $[32,45]$. The Fe $2 \mathrm{p}$ spectrum (Fig. $2 \mathrm{~b}$ ) presents two primary peaks at 706.9 and $719.8 \mathrm{eV}$, accompanied by two satellite peaks at 714.6 and $731.8 \mathrm{eV}$ corresponding to $\mathrm{Fe}^{3+} 2 \mathrm{p}_{3 / 2}$ and $\mathrm{Fe}^{3+} 2 \mathrm{p}_{1 / 2}$, respectively [46,47]. Another two characteristic peaks at binding energies of 709.4 and $724.2 \mathrm{eV}$ correspond to $\mathrm{Fe}^{2+} 2 \mathrm{p}_{3 / 2}$ and $\mathrm{Fe}^{2+} 2 \mathrm{p}_{1 / 2}$, respectively [48]. The XPS spectra demonstrate the coexistence of the $\mathrm{Fe}^{3+}$ and $\mathrm{Fe}^{2+}$ in the $\mathrm{P}_{-} \mathrm{Co}_{0.9} \mathrm{Ni}_{0.9} \mathrm{Fe}_{1.2} \mathrm{NCs}$.

The Co $2 \mathrm{p}$ spectrum in Fig. $2 \mathrm{c}$ can be divided into six characteristic peaks. The peaks at 778.7, 793.6, 780.6, and $797.8 \mathrm{eV}$ are assigned to $\mathrm{Co}^{2+} 2 \mathrm{p}_{3 / 2}, \mathrm{Co}^{2+} 2 \mathrm{p}_{1 / 2}, \mathrm{Co}^{3+} 2 \mathrm{p}_{3 / 2}$, and $\mathrm{Co}^{3+} 2 \mathrm{p}_{1 / 2}$, respectively. In addition, two satellite peaks correspond to the Co $2 \mathrm{p}$ region $[49,50]$, consistent with the binding energies of CoP species [51]. The Ni 2p spectrum can be deconvoluted into five peaks and two satellite peaks at 861.7 and $876.3 \mathrm{eV}$. The characteristic peaks at 853.6 and $870.5 \mathrm{eV}$ are attributed to $\mathrm{Ni}^{2+} 2 \mathrm{p}_{3 / 2}$ and $\mathrm{Ni}^{2+} 2 \mathrm{p}_{1 / 2}$ of the $\mathrm{Ni}$ species in $\mathrm{NiP}_{2}$, respectively, which are obviously shifted compared with the peak of standard $\mathrm{Ni}^{2+} 2 \mathrm{p}_{3 / 2}$ at $852.2 \mathrm{eV}$, indicating an electronic effect between the $\mathrm{Ni}^{2+}$ and $\mathrm{P}$ species (Fig. 2d). In addition, the peak at $856.1 \mathrm{eV}$ is ascribed to $\mathrm{Ni}^{2+}$ arising from surface oxidation $[52,53]$. Fig. 2e shows two dominant main peaks of $\mathrm{P}$ species, where the peaks at $129.4 \mathrm{eV}$ ( $\left.\mathrm{P} 2 \mathrm{p}_{3 / 2}\right)$ and $130.2 \mathrm{eV}\left(\mathrm{P} 2 \mathrm{p}_{1 / 2}\right)$ are well attributed to metal phosphides [54]. The peak at $134.1 \mathrm{eV}$ for $\mathrm{P}-\mathrm{O}$ is attributed to oxidized phosphate species as a result of partial exposure to air [55]. The C 1s spectrum is divided into four individual peaks (Fig. 2f). The characteristic peaks at 284.2 and $284.8 \mathrm{eV}$ correspond to $\mathrm{C}=\mathrm{C}$ and $\mathrm{C}-\mathrm{C}$ species, respectively [56]. The peak at $286.1 \mathrm{eV}$ represents the $\mathrm{C}-\mathrm{P}$ species, confirming the doping of $\mathrm{C}$ into sample. The peak at a binding energy of $289.1 \mathrm{eV}$ is attributed to $\mathrm{C}=\mathrm{O}$ bonds resulting from the oxidation of carbon [57].

The XPS spectra of the $\mathrm{P}_{-} \mathrm{Co}_{0.6} \mathrm{Ni}_{1.2} \mathrm{Fe}_{1.2} \mathrm{NCs}$ and $\mathrm{P}-\mathrm{Co}_{1.2} \mathrm{Ni}_{0.6} \mathrm{Fe}_{1.2} \mathrm{NCs}$ (Fig. S1) reveal the existence of the same main elements observed in the $\mathrm{P}-\mathrm{Co}_{0.9} \mathrm{Ni}_{0.9} \mathrm{Fe}_{1.2}$ $\mathrm{NCs}$, although the peak intensities vary with the initial amount of $\mathrm{Co}, \mathrm{Ni}$, and $\mathrm{Fe}$ species. As shown in Fig. S1b-d, the $\mathrm{P}-\mathrm{Co}_{0.6} \mathrm{Ni}_{1.2} \mathrm{Fe}_{1.2} \mathrm{NCs}$ and $\mathrm{P}-\mathrm{Co}_{1.2} \mathrm{Ni}_{0.6} \mathrm{Fe}_{1.2}$ NCs exhibit two different valences, consistent with the $\mathrm{P}^{-} \mathrm{Co}_{0.9} \mathrm{Ni}_{0.9} \mathrm{Fe}_{1.2}$ NCs $[47,50,52]$. The P $2 \mathrm{p}$ spectra in Fig. S2e can be divided into two species: metal phosphides and $\mathrm{P}-\mathrm{O}$ bonds [55]. Moreover, four peaks are distinctly observed in the $\mathrm{C}$ 1s spectrum (Fig. S2f), corresponding to $\mathrm{C}=\mathrm{O}, \mathrm{C}=\mathrm{C}, \mathrm{C}-\mathrm{C}$, and $\mathrm{C}-\mathrm{P}[56]$. The incorporation of $\mathrm{P}$ with nontoxic metallic elements of $\mathrm{Co}^{2+}, \mathrm{Co}^{3+}, \mathrm{Fe}^{2+}, \mathrm{Fe}^{3+}$, and $\mathrm{Ni}^{2+}$ can effectively increase the number of available
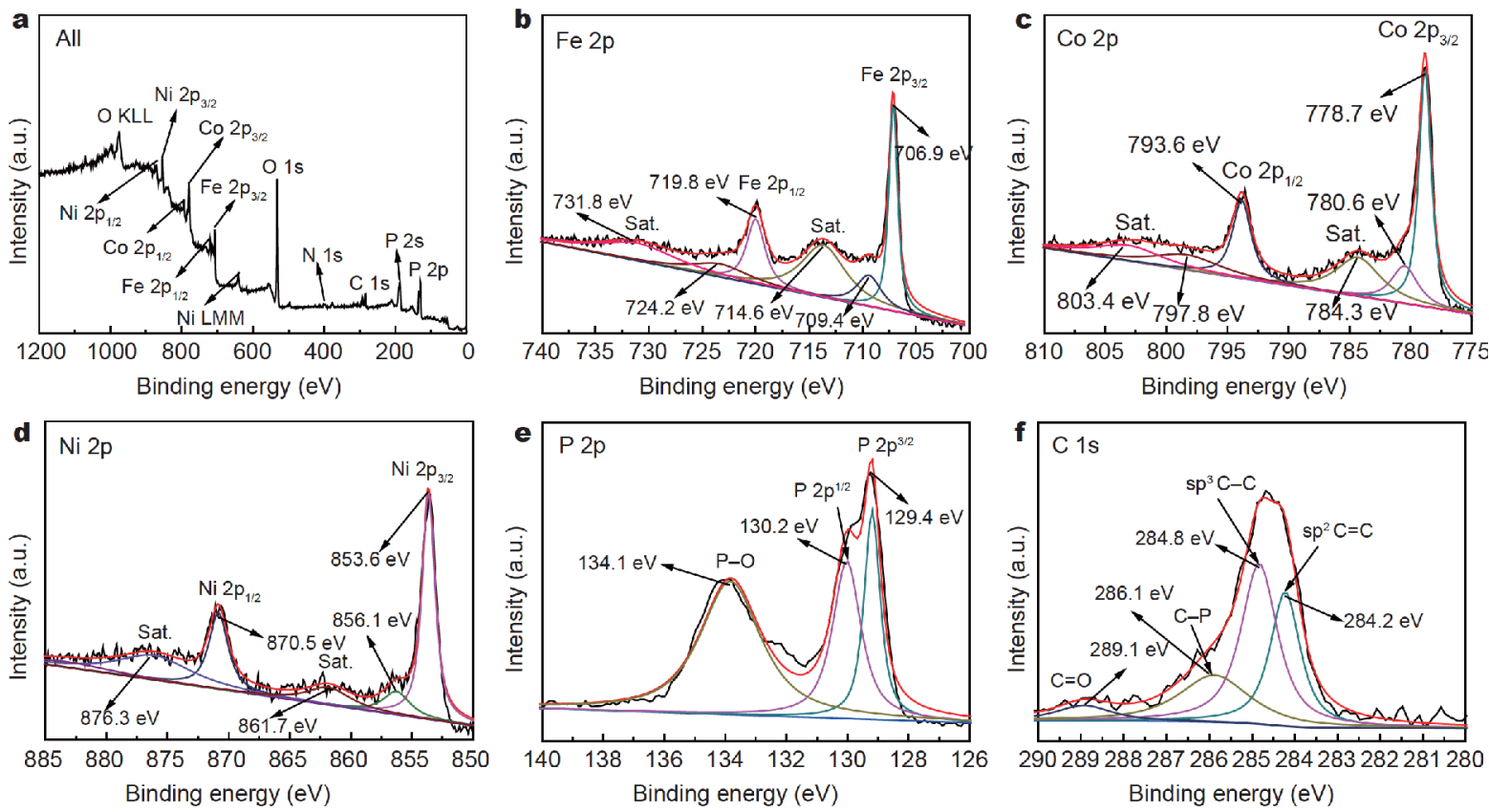

Figure 2 XPS spectra of the P-Co ${ }_{0.9} \mathrm{Ni}_{0.9} \mathrm{Fe}_{1.2}$ NCs: (a) survey; (b) Fe 2p; (c) Co 2p; (d) Ni 2p; (e) P 2p; and (f) C 1 s. 
active sites and further enhance the catalytic activities for HER and OER. Moreover, multiple-valence metal ions can also induce partial charge transfer and optimize the electronic structure, thereby improving the catalytic performance of the $\mathrm{P}_{-} \mathrm{Co}_{0.9} \mathrm{Ni}_{0.9} \mathrm{Fe}_{1.2}$ NCs.

SEM images (Fig. $3 \mathrm{a}-\mathrm{c}$ ) show that the $\mathrm{Co}_{0.9} \mathrm{Ni}_{0.9} \mathrm{Fe}_{1.2}$ NCs are composed of closely arranged and highly ordered NCs with a smooth surface. After facile phosphorization of the $\mathrm{Co}_{0.9} \mathrm{Ni}_{0.9} \mathrm{Fe}_{1.2} \mathrm{NC}$ precursors, the as-prepared P- $\mathrm{Co}_{0.9} \mathrm{Ni}_{0.9} \mathrm{Fe}_{1.2} \mathrm{NCs}$ maintain a cubic morphology with an average side length of $120-140 \mathrm{~nm}$; however, the surface becomes rougher than that of the $\mathrm{Co}_{0.9} \mathrm{Ni}_{0.9} \mathrm{Fe}_{1.2}$ NC precursors (Fig. 3d-f), indicating the formation of surface defects as exposed active sites. By comparison, the SEM images in Fig. S2a-c show that the $\mathrm{Ni}_{1.8} \mathrm{Fe}_{1.2} \mathrm{NCs}$ consist of tightly arranged NCs with a uniform side length of approximately $100 \mathrm{~nm}$. In Fig. S2d-f, the $\mathrm{Co}_{1.8} \mathrm{Fe}_{1.2} \mathrm{NCs}$ are observed to be composed of well-dispersed NCs with a smooth surface and a side length of approximately $120 \mathrm{~nm}$. Fig. S3a-f show SEM images of the as-prepared $\mathrm{Co}_{1.2} \mathrm{Ni}_{0.6} \mathrm{Fe}_{1.2} \mathrm{NCs}$ and $\mathrm{Co}_{0.6} \mathrm{Ni}_{1.2} \mathrm{Fe}_{1.2}$ $\mathrm{NCs}$, respectively. The images in Fig. $\mathrm{S} 3$ show that the surfaces of the $\mathrm{Co}_{1.2} \mathrm{Ni}_{0.6} \mathrm{Fe}_{1.2} \mathrm{NCs}$ and $\mathrm{Co}_{0.6} \mathrm{Ni}_{1.2} \mathrm{Fe}_{1.2} \mathrm{NCs}$ are smooth, providing abundant growth points for phosphorization. As shown in Fig. S4a-f, the bimetallic $\mathrm{P}-\mathrm{Ni}_{1.8} \mathrm{Fe}_{1.2} \mathrm{NCs}$ and $\mathrm{P}-\mathrm{Co}_{1.8} \mathrm{Fe}_{1.2}$ NCs maintain the cubic morphology of the precursors after phosphorization under an argon atmosphere, whereas their surface becomes extremely rough, implying the in situ construction of surface defects. SEM images of the P-Co $\mathrm{Co}_{1.2} \mathrm{Ni}_{0.6} \mathrm{Fe}_{1.2} \mathrm{NCs}$ and $\mathrm{P}-\mathrm{Co}_{0.6} \mathrm{Ni}_{1.2} \mathrm{Fe}_{1.2}$ NCs (Fig. S5a-f) show a highly ordered nanocubic morphology with a rougher surface. In conclusion, although the ratio of $\mathrm{Ni}, \mathrm{Fe}$, and $\mathrm{Co}$ species varies, the well-distributed NC morphology of the PBA is maintained. After phosphorization, the as-prepared phosphides maintain their original cubic morphology but with a rougher surface, which indicates more accessible active sites resulting from the in situ construction of surface defects.

The TEM images of the $\mathrm{P}-\mathrm{Co}_{0.9} \mathrm{Ni}_{0.9} \mathrm{Fe}_{1.2} \mathrm{NCs}$ in Fig. S6a-c indicate that the characteristic cubes exhibit cubic symmetry with distinct edges and corners resulting from the in situ formation of surface defects, consistent with the SEM observations. The high-magnification image in Fig. S6d shows that a typical NC is composed of a rugged margin to construct the three-dimensional architecture, further indicating that the $\mathrm{P}$ ions are adequately embedded into the $\mathrm{P}^{-} \mathrm{Co}_{0.9} \mathrm{Ni}_{0.9} \mathrm{Fe}_{1.2} \mathrm{NCs}$.

The HRTEM images of the $\mathrm{P}^{-} \mathrm{Co}_{0.9} \mathrm{Ni}_{0.9} \mathrm{Fe}_{1.2} \mathrm{NCs}$ in Fig. $4 \mathrm{a}-\mathrm{c}$ provide a distinct view of the lattice fringes from different regions. The selected area demonstrates lattice fringes with interplanar distances of $0.24,0.28,0.19,0.18$, and $0.25 \mathrm{~nm}$ corresponding to the (210), (131), (112), (211), and (-132) planes of $\mathrm{NiP}_{2}$ (PDF No. 01-073-0436), $\mathrm{FeP}_{4}$ (PDF No. 00-032-0470), CoP (PDF No. 00-0290497), CoP (PDF No. 00-029-0497), and $\mathrm{FeP}_{4}$ (PDF No. 00-032-0470), respectively, consistent with the XRD analysis. The presence of surface defects means that the
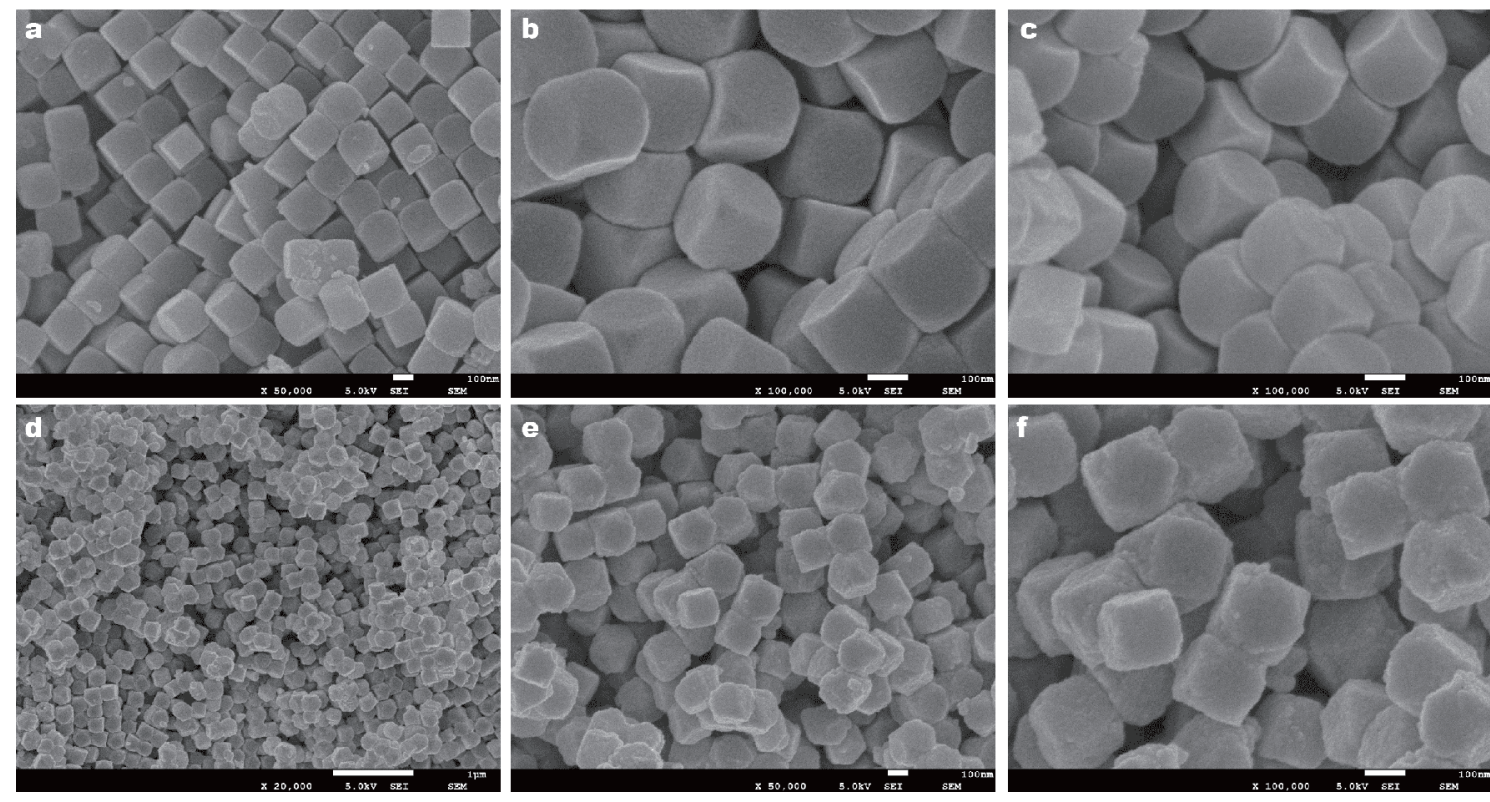

Figure 3 SEM images: $(\mathrm{a}-\mathrm{c}) \mathrm{Co}_{0.9} \mathrm{Ni}_{0.9} \mathrm{Fe}_{1.2} \mathrm{NCs}$ and $(\mathrm{d}-\mathrm{f}) \mathrm{P}_{-}-\mathrm{Co}_{0.9} \mathrm{Ni}_{0.9} \mathrm{Fe}_{1.2} \mathrm{NCs}$. 


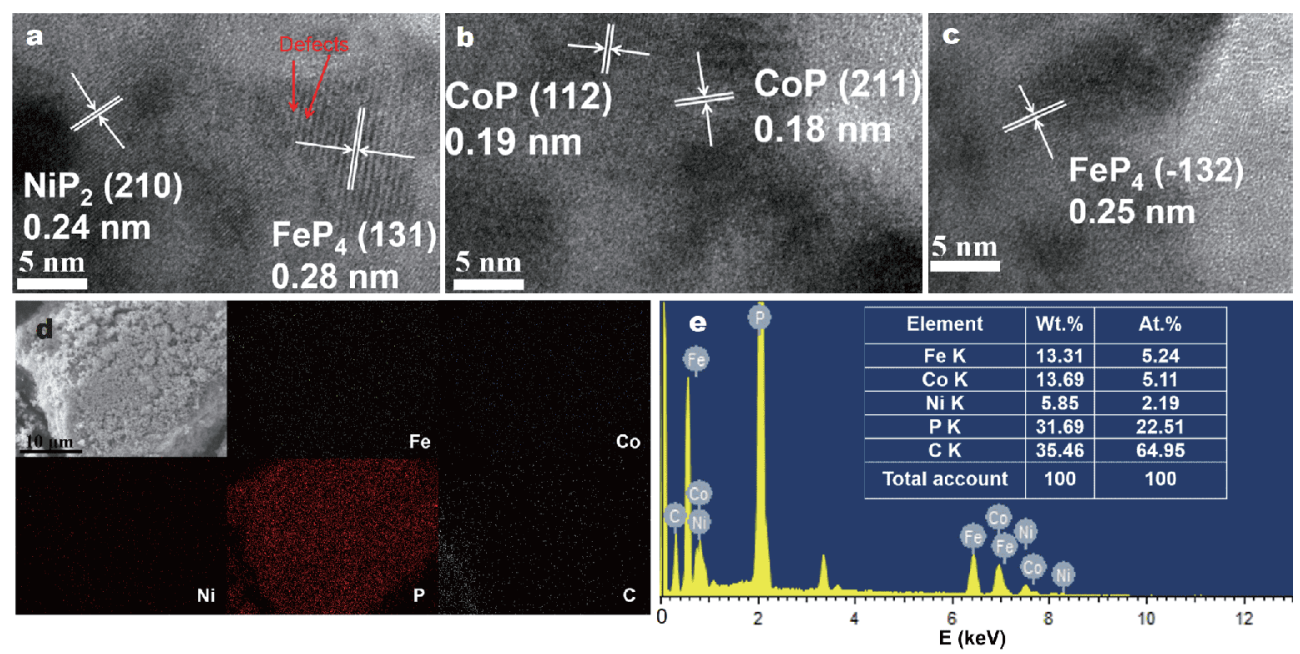

Figure 4 (a-c) HRTEM images, (d) SEM mapping image, and (e) EDX spectra of $\mathrm{P}-\mathrm{Co}_{0.9} \mathrm{Ni}_{0.9} \mathrm{Fe}_{1.2} \mathrm{NCs}$.

regular structure of the crystals is divided into numerous smaller regions by some interfaces and that each region has a high atomic array integrity. Serious atomic misalignments occur near the interface between the regions. The visualized manifestation is that the lattice fringes of the molecules appear at different intervals, and the phenomenon of defects occurring over the entire interface, as shown in Fig. 4a, is called surface defects. The rich defect structure can expose more real active sites, which essentially enhances the electrocatalytic performance of the P- $\mathrm{Co}_{0.9} \mathrm{Ni}_{0.9} \mathrm{Fe}_{1.2}$ NCs. Notably, P- $\mathrm{Co}_{0.9} \mathrm{Ni}_{0.9} \mathrm{Fe}_{1.2}$ NCs with rich surface defects are beneficial for improving the intrinsic electrochemical activities. Furthermore, Fig. 4d and e shows the SEM mapping image and the corresponding EDX spectra of the $\mathrm{P}-\mathrm{Co}_{0.9} \mathrm{Ni}_{0.9} \mathrm{Fe}_{1.2} \mathrm{NCs}$, which confirm that the $\mathrm{Fe}, \mathrm{Co}, \mathrm{Ni}, \mathrm{P}$, and $\mathrm{C}$ are homogenously distributed throughout the NCs. Fig. 4e shows that the weight percentage of $\mathrm{Fe}, \mathrm{Co}, \mathrm{Ni}, \mathrm{P}$, and $\mathrm{C}$ is $13.31 \%$, $13.69 \%, 5.85 \%, 31.69 \%$, and $35.46 \%$, respectively. The atomic number percentage of $\mathrm{P}-\mathrm{Co}_{0.9} \mathrm{Ni}_{0.9} \mathrm{Fe}_{1.2} \mathrm{NCs}$ is $5.24 \%, 5.11 \%, 2.19 \%, 22.51 \%$, and $64.95 \%$ for $\mathrm{Fe}, \mathrm{Co}, \mathrm{Ni}$, $\mathrm{P}$, and $\mathrm{C}$, respectively.

The electrocatalytic properties of the developed catalysts in $1.0 \mathrm{~mol} \mathrm{~L}^{-1} \mathrm{KOH}$ electrolyte solution for HER are presented in Fig. 5 and Fig. S7. Fig. $5 \mathrm{a}$ and Fig. S7a show the polarization curves of all of the prepared electrocatalysts. The $\mathrm{P}_{-} \mathrm{Co}_{0.9} \mathrm{Ni}_{0.9} \mathrm{Fe}_{1.2} \mathrm{NCs}$ exhibit an obviously smaller onset overpotential than the other samples, requiring a small overpotential of only $-200.7 \mathrm{mV}$ to deliver a current density of $10 \mathrm{~mA} \mathrm{~cm}{ }^{-2}$, demonstrating superior OER performance compared with the P- $\mathrm{Co}_{1.2} \mathrm{Ni}_{0.6} \mathrm{Fe}_{1.2} \mathrm{NCs}(-220.6 \mathrm{mV}), \mathrm{P}^{-} \mathrm{Co}_{0.6} \mathrm{Ni}_{1.2} \mathrm{Fe}_{1.2} \mathrm{NCs}$
(-243.2 mV), P-Co ${ }_{1.8} \mathrm{Fe}_{1.2}$ NCs $(-263.3 \mathrm{mV}), \mathrm{P}-\mathrm{Ni}_{1.8} \mathrm{Fe}_{1.2}$ NCs $\quad(-266.1 \mathrm{mV}), \quad \mathrm{Co}_{0.9} \mathrm{Ni}_{0.9} \mathrm{Fe}_{1.2} \quad \mathrm{NCs} \quad(-577.8 \mathrm{mV})$, $\mathrm{Co}_{1.8} \mathrm{Fe}_{1.2} \quad \mathrm{NCs} \quad(-584.1 \mathrm{mV}), \mathrm{Co}_{1.2} \mathrm{Ni}_{0.6} \mathrm{Fe}_{1.2} \quad \mathrm{NCs}$, $\mathrm{Co}_{0.6} \mathrm{Ni}_{1.2} \mathrm{Fe}_{1.2} \mathrm{NCs}$, and $\mathrm{Ni}_{1.8} \mathrm{Fe}_{1.2}$ NCs. Compared with the catalytic performance of other phosphides, that of the $\mathrm{P}-\mathrm{Co}_{0.9} \mathrm{Ni}_{0.9} \mathrm{Fe}_{1.2} \mathrm{NCs}$ is also closest to the performance of $\mathrm{Pt} / \mathrm{C}$.

Fig. 5b and Fig. S7b show that the Tafel plots of the P- $\mathrm{Co}_{0.9} \mathrm{Ni}_{0.9} \mathrm{Fe}_{1.2} \mathrm{NCs}$ of $50.5 \mathrm{mV} \mathrm{dec}{ }^{-1}$ are much smaller than those of $\mathrm{P}_{-} \mathrm{Co}_{1.2} \mathrm{Ni}_{0.6} \mathrm{Fe}_{1.2} \mathrm{NCs}\left(63.5 \mathrm{mV} \mathrm{dec}{ }^{-1}\right)$, P- $\mathrm{Co}_{0.6} \mathrm{Ni}_{1.2} \mathrm{Fe}_{1.2}$ NCs $\left(76.3 \mathrm{mV} \mathrm{dec}{ }^{-1}\right), \quad$ P-Co $\mathrm{Co}_{1.8} \mathrm{Fe}_{1.2}$ NCs $\left(85.0 \mathrm{mV} \mathrm{dec}{ }^{-1}\right), \quad \mathrm{P}^{-\mathrm{Ni}_{1.8}} \mathrm{Fe}_{1.2} \quad \mathrm{NCs} \quad\left(91.5 \mathrm{mV} \mathrm{dec}^{-1}\right)$, $\mathrm{Co}_{0.9} \mathrm{Ni}_{0.9} \mathrm{Fe}_{1.2} \quad$ NCs $\quad\left(100.8 \mathrm{mV} \mathrm{dec}{ }^{-1}\right), \quad \mathrm{Co}_{1.8} \mathrm{Fe}_{1.2} \quad \mathrm{NCs}$ $\left(103.5 \mathrm{mV} \mathrm{dec}{ }^{-1}\right), \mathrm{Co}_{1.2} \mathrm{Ni}_{0.6} \mathrm{Fe}_{1.2} \mathrm{NCs}\left(154.5 \mathrm{mV} \mathrm{dec}{ }^{-1}\right)$, $\mathrm{Co}_{0.6} \mathrm{Ni}_{1.2} \mathrm{Fe}_{1.2}$ NCs $\left(200.3 \mathrm{mV} \mathrm{dec}{ }^{-1}\right)$, and $\mathrm{Ni}_{1.8} \mathrm{Fe}_{1.2} \mathrm{NCs}$ $\left(290.1 \mathrm{mV} \mathrm{dec}^{-1}\right)$, implying favorable kinetics performance for OER. On the basis of the results in Table S1, the properties of the $\mathrm{P}-\mathrm{Co}_{0.9} \mathrm{Ni}_{0.9} \mathrm{Fe}_{1.2}$ NCs are substantially better than those of other reported transitionmetal phosphides, indicating remarkable reaction kinetics and a fast rate of oxygen generation for HER.

EIS plots were further used to show the various charge transfer resistance $\left(R_{\mathrm{ct}}\right)$ of all of the prepared electrocatalysts. Fig. $5 c$ and Fig. S7c present the semicircular EIS plots, which are related to the charge transfer rate between the catalysts and the electrolyte. The results reveal that the $\mathrm{P}_{-} \mathrm{Co}_{0.9} \mathrm{Ni}_{0.9} \mathrm{Fe}_{1.2} \mathrm{NCs}$ present extremely lower charge transfer resistance than other prepared electrocatalysts. The $C_{\mathrm{dl}}$ in Fig. $5 \mathrm{~d}$ and Fig. S7d, which was determined from the dependent CV curves (Fig. S8a), further demonstrates the intrinsic activities of the prepared electrocatalysts. The $C_{\mathrm{dl}}$ value for the $\mathrm{P}_{-} \mathrm{Co}_{0.9} \mathrm{Ni}_{0.9^{-}}$ 

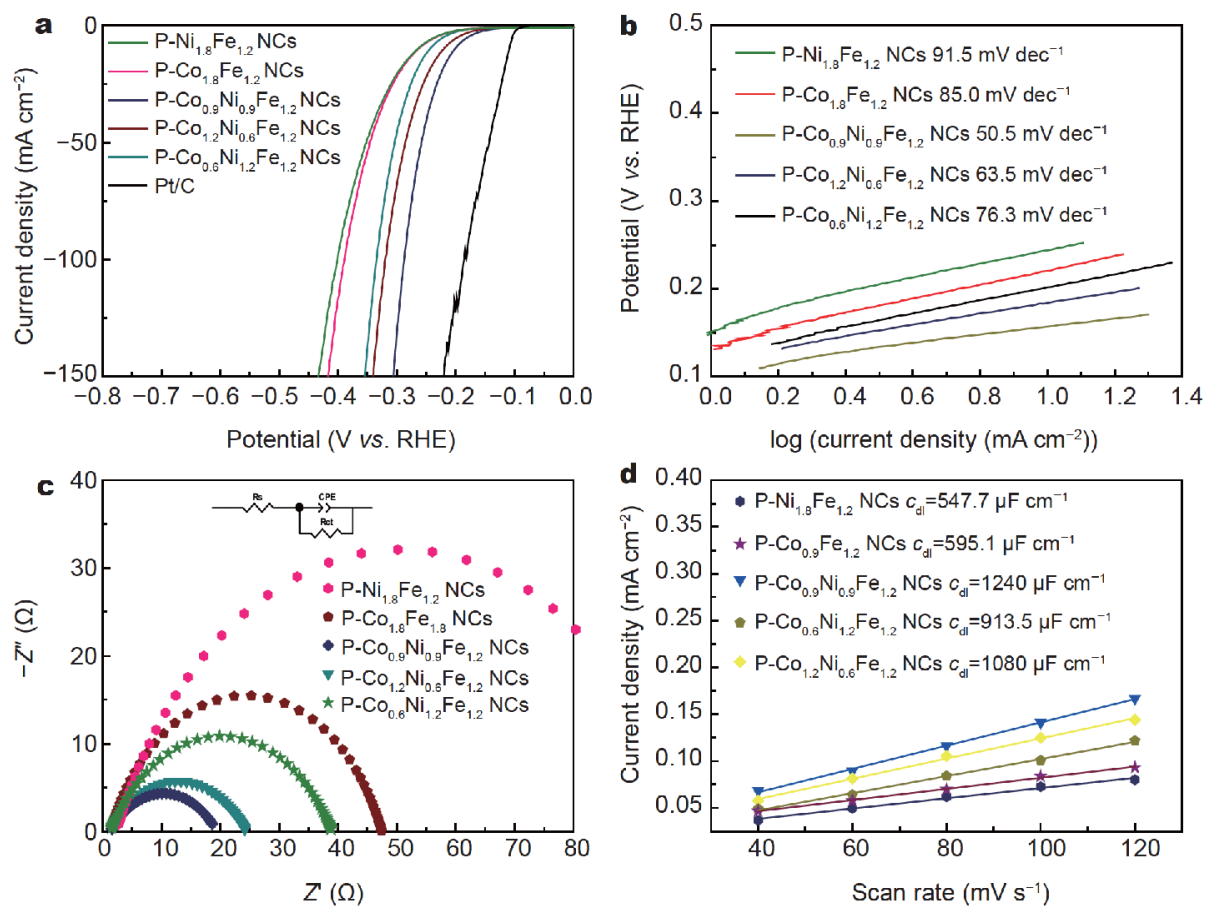

Figure 5 HER electrochemical performances of the P- $\mathrm{Ni}_{1.8} \mathrm{Fe}_{1.2} \mathrm{NCs}, \mathrm{P}-\mathrm{Co}_{1.8} \mathrm{Fe}_{1.2} \quad \mathrm{NCs}, \mathrm{P}-\mathrm{Co}_{0.9} \mathrm{Ni}_{0.9} \mathrm{Fe}_{1.2} \quad \mathrm{NCs}, \mathrm{P}-\mathrm{Co} \mathrm{o}_{1.2} \mathrm{Ni}_{0.6} \mathrm{Fe}_{1.2} \quad \mathrm{NCs}$, and the P- $\mathrm{Co}_{0.6} \mathrm{Ni}_{1.2} \mathrm{Fe}_{1.2} \mathrm{NCs}$ in $1 \mathrm{~mol} \mathrm{~L}-1 \mathrm{KOH}$ : (a) LSVs; (b) Tafel plots; (c) Nyquist plots; and (d) the determined double-layer capacitance $\left(C_{\mathrm{dl}}\right)$ values.

$\mathrm{Fe}_{1.2} \mathrm{NCs}$ is $1,240 \mu \mathrm{F} \mathrm{cm}{ }^{-2}$, which is larger than those of the $\mathrm{P}-\mathrm{Co}_{1.2} \mathrm{Ni}_{0.6} \mathrm{Fe}_{1.2} \mathrm{NCs}\left(1,080 \mu \mathrm{F} \mathrm{cm}{ }^{-2}\right), \mathrm{P}_{-} \mathrm{Co}_{0.6} \mathrm{Ni}_{1.2} \mathrm{Fe}_{1.2}$ NCs $\left(913.5 \mu \mathrm{F} \mathrm{cm}^{-2}\right), \quad \mathrm{P}^{-} \mathrm{Co}_{1.8} \mathrm{Fe}_{1.2} \mathrm{NCs}\left(595.1 \mu \mathrm{F} \mathrm{cm}{ }^{-2}\right)$, P- $\mathrm{Ni}_{1.8} \mathrm{Fe}_{1.2} \quad \mathrm{NCs} \quad\left(547.7 \mu \mathrm{F} \mathrm{cm}{ }^{-2}\right), \quad \mathrm{Co}_{0.9} \mathrm{Ni}_{0.9} \mathrm{Fe}_{1.2} \quad \mathrm{NCs}$ $\left(295.6 \mu \mathrm{F} \mathrm{cm}{ }^{-2}\right), \mathrm{Co}_{1.8} \mathrm{Fe}_{1.2} \mathrm{NCs}\left(269.2 \mu \mathrm{F} \mathrm{cm}^{-2}\right), \mathrm{Co}_{1.2^{-}}$ $\mathrm{Ni}_{0.6} \mathrm{Fe}_{1.2} \quad \mathrm{NCs} \quad\left(173.7 \mu \mathrm{F} \mathrm{cm}{ }^{-2}\right), \quad \mathrm{Co}_{0.6} \mathrm{Ni}_{1.2} \mathrm{Fe}_{1.2} \quad \mathrm{NCs}$ $\left(109.9 \mu \mathrm{F} \mathrm{cm}^{-2}\right)$, and $\mathrm{Ni}_{1.8} \mathrm{Fe}_{1.2} \mathrm{NCs}\left(70.2 \mu \mathrm{F} \mathrm{cm}^{-2}\right)$, implying that the $\mathrm{P}-\mathrm{Co}_{0.9} \mathrm{Ni}_{0.9} \mathrm{Fe}_{1.2} \mathrm{NCs}$ exhibit a large electrochemical surface area for the OER.

The OER properties of all of the prepared electrocatalysts in $1.0 \mathrm{~mol} \mathrm{~L}^{-1} \mathrm{KOH}$ electrolyte are shown in Fig. 6 and Fig. S9. The results in Fig. 6a and Fig. S9a clearly show that the $\mathrm{P}-\mathrm{Co}_{0.9} \mathrm{Ni}_{0.9} \mathrm{Fe}_{1.2} \mathrm{NCs}$ exhibit a much smaller onset overpotential compared with the other investigated electrocatalysts. To achieve a current density of $10 \mathrm{~mA} \mathrm{~cm}{ }^{-2}$, the $\mathrm{P}_{-} \mathrm{Co}_{0.9} \mathrm{Ni}_{0.9} \mathrm{Fe}_{1.2} \mathrm{NCs}$ require an extremely small overpotential of $273.1 \mathrm{mV}$. This overpotential is substantially smaller than those of the P- $\mathrm{Co}_{0.6} \mathrm{Ni}_{1.2} \mathrm{Fe}_{1.2}$ NCs (305.1 mV), P- $\mathrm{Co}_{1.2} \mathrm{Ni}_{0.6} \mathrm{Fe}_{1.2} \mathrm{NCs}$ (318.6 mV), P- $\mathrm{Co}_{1.8} \mathrm{Fe}_{1.2} \quad \mathrm{NCs}(327.2 \mathrm{mV}), \quad \mathrm{P}-\mathrm{Ni}_{1.8} \mathrm{Fe}_{1.2}$ NCs $\quad(328.4 \mathrm{mV}), \quad \mathrm{Co}_{0.9} \mathrm{Ni}_{0.9} \mathrm{Fe}_{1.2} \quad \mathrm{NCs} \quad(470.6 \mathrm{mV})$, $\mathrm{Co}_{1.8} \mathrm{Fe}_{1.2}$ NCs $(499.7 \mathrm{mV}), \mathrm{Ni}_{1.8} \mathrm{Fe}_{1.2} \mathrm{NCs}, \mathrm{Co}_{1.2} \mathrm{Ni}_{0.6} \mathrm{Fe}_{1.2}$ $\mathrm{NCs}$, and $\mathrm{Co}_{0.6} \mathrm{Ni}_{1.2} \mathrm{Fe}_{1.2}$ NCs. Fig. 6a shows that the catalytic performances of the $\mathrm{P}-\mathrm{Co}_{0.9} \mathrm{Ni}_{0.9} \mathrm{Fe}_{1.2} \mathrm{NCs}, \mathrm{P}-\mathrm{Co}_{0.6}$ $\mathrm{Ni}_{1.2} \mathrm{Fe}_{1.2}$ NCs, P-Co ${ }_{1.2} \mathrm{Ni}_{0.6} \mathrm{Fe}_{1.2}$ NCs, P- $\mathrm{Co}_{1.8} \mathrm{Fe}_{1.2}$ NCs, and $\mathrm{P}-\mathrm{Ni}_{1.8} \mathrm{Fe}_{1.2} \mathrm{NCs}$ are substantially better than that of the commercial $\mathrm{RuO}_{2}$. In the plots of the Tafel slopes (Fig. 6b and Fig. S9b), the P- $\mathrm{Co}_{0.9} \mathrm{Ni}_{0.9} \mathrm{Fe}_{1.2}$ NCs show a value of $46.9 \mathrm{mV} \mathrm{dec}^{-1}$, which is much smaller than those of the $\mathrm{P}-\mathrm{Co}_{0.6} \mathrm{Ni}_{1.2} \mathrm{Fe}_{1.2}$ NCs, P- $\mathrm{Co}_{1.2} \mathrm{Ni}_{0.6} \mathrm{Fe}_{1.2}$ NCs, P-Co ${ }_{1.8} \mathrm{Fe}_{1.2}$ NCs, P- $\mathrm{Ni}_{1.8} \mathrm{Fe}_{1.2}$ NCs, $\mathrm{Co}_{0.9} \mathrm{Ni}_{0.9} \mathrm{Fe}_{1.2}$ NCs, $\mathrm{Co}_{1.8} \mathrm{Fe}_{1.2} \mathrm{NCs}, \mathrm{Ni}_{1.8} \mathrm{Fe}_{1.2} \mathrm{NCs}, \mathrm{Co}_{1.2} \mathrm{Ni}_{0.6} \mathrm{Fe}_{1.2} \mathrm{NCs}$, and $\mathrm{Co}_{0.6} \mathrm{Ni}_{1.2} \mathrm{Fe}_{1.2}$ NCs $(61.0,69.6,75.2,86.4,119.1,138.5$, 157.8, 225.8, and $386.0 \mathrm{mV} \mathrm{dec}^{-1}$, respectively), implying higher OER kinetics. As shown in Table S2, the catalytic properties of $\mathrm{P}-\mathrm{Co}_{0.9} \mathrm{Ni}_{0.9} \mathrm{Fe}_{1.2} \mathrm{NCs}$ are better than those of most previously reported transition-metal phosphides, indicating the remarkable reaction kinetics and fast rate of oxygen generation for OER.

Nyquist plots (EIS) of all the electrocatalysts (Fig. 6c and Fig. $59 \mathrm{c}$ ) demonstrate that the $R_{\mathrm{ct}}$ values of the investigated electrocatalysts increase in the following order: $\mathrm{P}-\mathrm{Co}_{0.9} \mathrm{Ni}_{0.9} \mathrm{Fe}_{1.2} \mathrm{NCs}<\mathrm{P}_{-} \mathrm{Co}_{0.6} \mathrm{Ni}_{1.2} \mathrm{Fe}_{1.2} \mathrm{NCs}<\mathrm{P}^{-} \mathrm{Co}_{1.2}{ }^{-}$ $\mathrm{Ni}_{0.6} \mathrm{Fe}_{1.2} \mathrm{NCs}<\mathrm{P}-\mathrm{Co}_{1.8} \mathrm{Fe}_{1.2} \mathrm{NCs}<\mathrm{P}-\mathrm{Ni}_{1.8} \mathrm{Fe}_{1.2} \mathrm{NCs}<$ $\mathrm{Co}_{0.9} \mathrm{Ni}_{0.9} \mathrm{Fe}_{1.2} \mathrm{NCs}<\mathrm{Co}_{1.8} \mathrm{Fe}_{1.2} \mathrm{NCs}<\mathrm{Ni}_{1.8} \mathrm{Fe}_{1.2} \mathrm{NCs}<$ $\mathrm{Co}_{1.2} \mathrm{Ni}_{0.6} \mathrm{Fe}_{1.2} \mathrm{NCs}<\mathrm{Co}_{0.6} \mathrm{Ni}_{1.2} \mathrm{Fe}_{1.2}$ NCs. The extremely smaller $R_{\mathrm{ct}}$ of the $\mathrm{P}_{-} \mathrm{Co}_{0.9} \mathrm{Ni}_{0.9} \mathrm{Fe}_{1.2} \mathrm{NCs}$ indicates a faster rate of charge transfer during the OER catalytic process, which is beneficial for oxygen generation. We estimated the electrochemically active surface areas by calculating the $C_{\mathrm{dl}}$ values (in Fig. $6 \mathrm{~d}$ and Fig. S9b, d). The values of $C_{\mathrm{dl}}$ for $\mathrm{P}-\mathrm{Co}_{0.9} \mathrm{Ni}_{0.9} \mathrm{Fe}_{1.2}$ NCs, $\mathrm{P}-\mathrm{Co}_{0.6} \mathrm{Ni}_{1.2} \mathrm{Fe}_{1.2}$ NCs, 

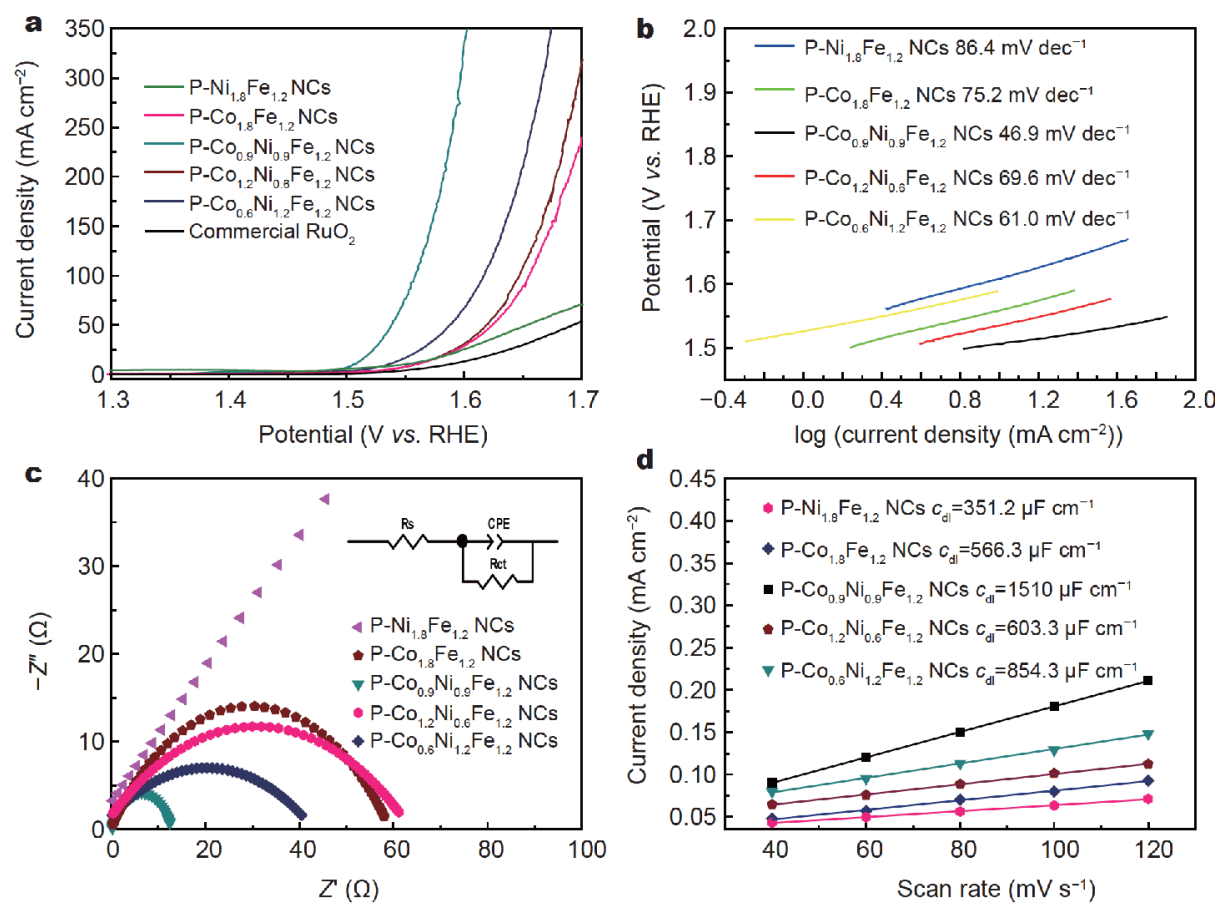

Figure 6 OER electrochemical performances of the P- $\mathrm{Ni}_{1.8} \mathrm{Fe}_{1.2} \quad \mathrm{NCs}, \quad \mathrm{P}-\mathrm{Co}_{1.8} \mathrm{Fe}_{1.2} \quad \mathrm{NCs}, \quad \mathrm{P}-\mathrm{Co}_{0.9} \mathrm{Ni}_{0.9} \mathrm{Fe}_{1.2} \quad \mathrm{NCs} \quad \mathrm{P}-\mathrm{Co}_{1.2} \mathrm{Ni}_{0.6} \mathrm{Fe}_{1.2} \quad \mathrm{NCs}$ and P- $\mathrm{Co}_{0.6} \mathrm{Ni}_{1.2} \mathrm{Fe}_{1.2} \mathrm{NCs}$ in $1.0 \mathrm{~mol} \mathrm{~L}$-1 KOH. (a) LSVs; (b) Tafel plots; (c) Nyquist plots; and (d) the determined double-layer capacitance $\left(C_{\mathrm{dl}}\right)$.

P- $\mathrm{Co}_{1.2} \mathrm{Ni}_{0.6} \mathrm{Fe}_{1.2} \mathrm{NCs}, \mathrm{P}-\mathrm{Co}_{1.8} \mathrm{Fe}_{1.2}$ NCs, P- $\mathrm{Ni}_{1.8} \mathrm{Fe}_{1.2} \mathrm{NCs}$, $\mathrm{Co}_{0.9} \mathrm{Ni}_{0.9} \mathrm{Fe}_{1.2}$ NCs, $\mathrm{Co}_{1.8} \mathrm{Fe}_{1.2}$ NCs, $\mathrm{Ni}_{1.8} \mathrm{Fe}_{1.2}$ NCs, $\mathrm{Co}_{1.2^{-}}$ $\mathrm{Ni}_{0.6} \mathrm{Fe}_{1.2} \mathrm{NCs}$, and $\mathrm{Co}_{0.6} \mathrm{Ni}_{1.2} \mathrm{Fe}_{1.2} \mathrm{NCs}$ were calculated to be $1,510,854.3,603.3,566.3,351.2,258.2,240.9,128.1$, 97.7, $78.9 \mu \mathrm{F} \mathrm{cm}^{-2}$, respectively. The larger $C_{\mathrm{dl}}$ of $\mathrm{P}-\mathrm{Co}_{0.9} \mathrm{Ni}_{0.9} \mathrm{Fe}_{1.2}$ NCs demonstrates that abundant electrochemically active sites are exposed for enhanced OER.

In addition, the BET specific surface area of the prepared $\mathrm{P}_{-} \mathrm{Co}_{0.9} \mathrm{Ni}_{0.9} \mathrm{Fe}_{1.2}$ NCs was determined from nitrogen adsorption and desorption isotherms. As shown in Fig. S10a and $\mathrm{S} 10 \mathrm{~b}$, the prepared $\mathrm{P}-\mathrm{Co}_{0.9} \mathrm{Ni}_{0.9} \mathrm{Fe}_{1.2} \mathrm{NCs}$ exhibit a large specific surface area of $310.7 \mathrm{~m}^{2} \mathrm{~g}^{-1}$ as well as an average pore size of $3.1 \mathrm{~nm}$. These results also indicate that the $\mathrm{P}_{-} \mathrm{Co}_{0.9} \mathrm{Ni}_{0.9} \mathrm{Fe}_{1.2} \mathrm{NCs}$ with a large BET specific surface area and a mesopore-rich surface expose more electrochemical effective active sites, thus accelerating electron transfer and promoting the penetration of electrolyte to enhance HER and OER.

The long-term stability of the prepared $\mathrm{P}-\mathrm{Co}_{0.9} \mathrm{Ni}_{0.9} \mathrm{Fe}_{1.2}$ NCs for HER and OER was characterized in $1.0 \mathrm{~mol} \mathrm{~L}^{-1}$ $\mathrm{KOH}$ electrolyte (Figs S11 and S12). Polarization curves of the $\mathrm{P}_{-}-\mathrm{Co}_{0.9} \mathrm{Ni}_{0.9} \mathrm{Fe}_{1.2}$ NCs before and after 1,000 continuous CV cycles for the HER and the OER at a scan rate of $100 \mathrm{mV} \mathrm{s}^{-1}$ are shown in Figs S11a and S12a, respectively. After the CV scanning, an insignificant change in current density in the polarization curves is observed, indicating substantial durability of the electrocatalyst for HER and OER. Correspondingly, chronoamperometry tests were conducted for $12 \mathrm{~h}$ to further evaluate the longterm stability of the prepared $\mathrm{P}-\mathrm{Co}_{0.9} \mathrm{Ni}_{0.9} \mathrm{Fe}_{1.2} \mathrm{NCs}$ for HER and OER. As shown in Figs S11b and S12b, the prepared $\mathrm{P}-\mathrm{Co}_{0.9} \mathrm{Ni}_{0.9} \mathrm{Fe}_{1.2} \mathrm{NCs}$ are extremely stable over $12 \mathrm{~h}$, exhibiting a negligible current loss for both HER and OER, thereby confirming the excellent durability of this catalyst. In addition, a comparison of the SEM (Fig. S13) and XPS (Fig. S14) data before and after the chronoamperometry stability test reveals that the $\mathrm{P}-\mathrm{Co}_{0.9} \mathrm{Ni}_{0.9} \mathrm{Fe}_{1.2} \mathrm{NCs}$ after the stability polarization test retain their cubic morphology with the valence of each element unchanged in HER and OER.

On the basis of the aforementioned analyses, the P- $\mathrm{Co}_{0.9} \mathrm{Ni}_{0.9} \mathrm{Fe}_{1.2}$ NCs exhibit favorable catalytic performance for both HER and OER in $1.0 \mathrm{~mol} \mathrm{~L}^{-1} \mathrm{KOH}$ electrolyte. Therefore, the $\mathrm{P}-\mathrm{Co}_{0.9} \mathrm{Ni}_{0.9} \mathrm{Fe}_{1.2} \mathrm{NCs}$ assembled as both cathodic and anodic catalysts were prepared to investigate the activities for overall water splitting. As expected, the prepared electrolyzer exhibits a smaller overpotential of $1.52 \mathrm{~V}$ to reach a current density of $10 \mathrm{~mA} \mathrm{~cm}^{-2}$ (Fig. 7a), which indicates that the $\mathrm{P}^{-} \mathrm{Co}_{0.9^{-}}$$\mathrm{Ni}_{0.9} \mathrm{Fe}_{1.2} \mathrm{NCs}$ are effective electrocatalysts for overall water splitting. The XRD pattern of the $\mathrm{P}-\mathrm{Co}_{0.9} \mathrm{Ni}_{0.9} \mathrm{Fe}_{1.2}$ NCs before and after the catalytic performance test for 

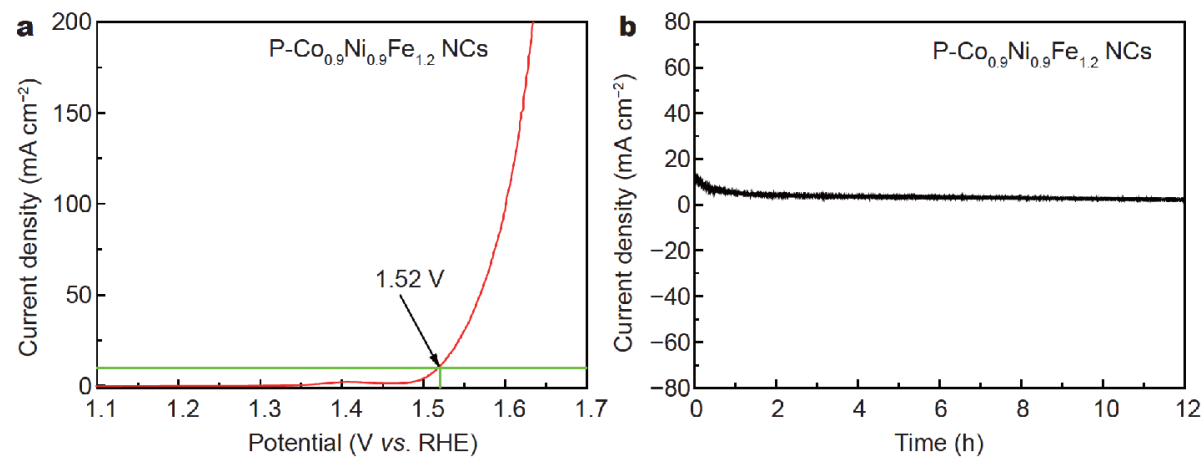

Figure 7 (a) Polarization curves in $1.0 \mathrm{~mol} \mathrm{~L}^{-1} \mathrm{KOH}$ for electrocatalysts whose anode and cathode both contain P-Co $\mathrm{Co}_{0.9} \mathrm{Ni}_{0.9} \mathrm{Fe}_{1.2} \mathrm{NCs}$ (b) The current density as a function of time at a potential of $1.52 \mathrm{~V}(v s$. RHE).

overall water splitting (Fig. S15) demonstrates that the dominant diffraction peaks of $\mathrm{P}-\mathrm{Co}_{0.9} \mathrm{Ni}_{0.9} \mathrm{Fe}_{1.2} \mathrm{NCs}$ do not change after the overall water splitting test, indicating that the crystalline structure and composition of the $\mathrm{P}-\mathrm{Co}_{0.9} \mathrm{Ni}_{0.9} \mathrm{Fe}_{1.2} \mathrm{NCs}$ are retained after the overall water splitting reaction. In addition, the SEM images of the $\mathrm{P}-\mathrm{Co}_{0.9} \mathrm{Ni}_{0.9} \mathrm{Fe}_{1.2} \mathrm{NCs}$ after the catalytic performance test for overall water splitting (Fig. S16) show that the $\mathrm{P}-\mathrm{Co}_{0.9} \mathrm{Ni}_{0.9} \mathrm{Fe}_{1.2} \mathrm{NCs}$ maintain the morphology of the NC structure with negligible etching of the edges after the overall water splitting test and the NCs still provide a large surface area for further catalytic reaction [58]. The chronoamperometry test at a voltage of $0.45 \mathrm{~V}$ ( $v$ s. SCE) for overall water splitting has also been investigated (Fig. 7b). The result shows that the prepared electrolyzer can maintain a nearly constant current density for $12 \mathrm{~h}$, demonstrating remarkable stability of the $\mathrm{P}-\mathrm{Co}_{0.9} \mathrm{Ni}_{0.9} \mathrm{Fe}_{1.2}$ NCs.

The excellent electrochemical performance of the $\mathrm{P}-\mathrm{Co}_{0.9} \mathrm{Ni}_{0.9} \mathrm{Fe}_{1.2} \mathrm{NCs}$ for overall water splitting is attributed to the following aspects: (1) the synergistic effect among different metal ions, $\mathrm{P}$, and $\mathrm{C}$ improves the intrinsic activities for both HER and OER; (2) the welldispersed cubic structures with a rough surface and rich defect concentration can expose rich active sites and ensure sufficient contact between the electrolyte and the P- $\mathrm{Co}_{0.9} \mathrm{Ni}_{0.9} \mathrm{Fe}_{1.2} \mathrm{NCs}$; (3) the C-doping can optimize the electronic structure of $\mathrm{P}, \mathrm{Fe}, \mathrm{Co}$, and $\mathrm{Ni}$ and improve the conductivity of the $\mathrm{P}-\mathrm{Co}_{0.9} \mathrm{Ni}_{0.9} \mathrm{Fe}_{1.2} \mathrm{NCs}$ for HER and OER.

\section{CONCLUSIONS}

In summary, ternary $\mathrm{P}_{-} \mathrm{Co}_{0.9} \mathrm{Ni}_{0.9} \mathrm{Fe}_{1.2} \mathrm{NCs}$ based on PBA possess obvious advantages, including enhanced intrinsic activity and the rich defects on the rough surface, suggesting excellent performance for overall water splitting.
The electrochemical measurements confirm that the optimized $\mathrm{P}-\mathrm{Co}_{0.9} \mathrm{Ni}_{0.9} \mathrm{Fe}_{1.2}$ NCs show prominent catalytic activities and remarkable durability for HER and OER. This work provides a promising strategy to design multimetal phosphides with rich defects as excellent electrocatalysts for overall water splitting.

Received 23 February 2019; accepted 28 April 2019;

published online 23 May 2019

1 Yang $\mathrm{H}$, Wang $\mathrm{X}$. Secondary-component incorporated hollow MOFs and derivatives for catalytic and energy-related applications. Adv Mater, 2018, 341: 1800743

2 Lin H, Li Y, Li H, et al. Multi-node CdS hetero-nanowires grown with defect-rich oxygen-doped $\mathrm{MoS}_{2}$ ultrathin nanosheets for efficient visible-light photocatalytic $\mathrm{H}_{2}$ evolution. Nano Res, 2017, 10: $1377-1392$

3 Xu ZJ. From two-phase to three-phase: The new electrochemical interface by oxide electrocatalysts. Nano-Micro Lett, 2018, 10: 8

4 Xiao Y, Tian C, Tian M, et al. Cobalt-vanadium bimetal-based nanoplates for efficient overall water splitting. Sci China Mater, 2018, 61: 80-90

5 Tang C, Wang HF, Zhang Q. Multiscale principles to boost reactivity in gas-involving energy electrocatalysis. Acc Chem Res, 2018, 51: 881-889

6 Yang H, Wang C, Hu F, et al. Atomic-scale Pt clusters decorated on porous $\alpha-\mathrm{Ni}(\mathrm{OH})_{2}$ nanowires as highly efficient electrocatalyst for hydrogen evolution reaction. Sci China Mater, 2017, 60: 11211128

7 Sial MAZG, Lin H, Wang X. Microporous 2D NiCoFe phosphate nanosheets supported on $\mathrm{Ni}$ foam for efficient overall water splitting in alkaline media. Nanoscale, 2018, 10: 12975-12980

8 Xiong X, Cai Z, Zhou D, et al. A highly-efficient oxygen evolution electrode based on defective nickel-iron layered double hydroxide. Sci China Mater, 2018, 61: 939-947

9 Li M, Tu X, Wang Y, et al. Highly enhanced visible-light-driven photoelectrochemical performance of ZnO-modified $\operatorname{In}_{2} \mathrm{~S}_{3}$ nanosheet arrays by atomic layer deposition. Nano-Micro Lett, 2018, 10: 45

10 Wei J, Zhou M, Long A, et al. Heterostructured electrocatalysts for hydrogen evolution reaction under alkaline conditions. NanoMicro Lett, 2018, 10: 75 
$11 \mathrm{Hu} \mathrm{WH}$, Shang X, Xue J, et al. Activating $\mathrm{MoS}_{2} / \mathrm{CNs}$ by tuning (001) plane as efficient electrocatalysts for hydrogen evolution reaction. Int J Hydrogen Energy, 2017, 42: 2088-2095

12 Shang X, Chi JQ, Lu SS, et al. Novel $\mathrm{Co}_{x} \mathrm{~S}_{y} / \mathrm{WS}_{2}$ nanosheets supported on carbon cloth as efficient electrocatalyst for hydrogen evolution reaction. Int J Hydrogen Energy, 2017, 42: 4165-4173

13 Zheng YR, Wu P, Gao MR, et al. Doping-induced structural phase transition in cobalt diselenide enables enhanced hydrogen evolution catalysis. Nat Commun, 2018, 9: 2533

14 Zhang S, Ni B, Li H, et al. Cobalt carbonate hydroxide superstructures for oxygen evolution reactions. Chem Commun, 2017, 53: $8010-8013$

15 Shang X, Dong B, Chai YM, et al. In-situ electrochemical activation designed hybrid electrocatalysts for water electrolysis. Sci Bull, 2018, 63: 853-876

16 Ma TY, Dai S, Jaroniec M, et al. Metal-organic framework derived hybrid $\mathrm{Co}_{3} \mathrm{O}_{4}$-carbon porous nanowire arrays as reversible oxygen evolution electrodes. J Am Chem Soc, 2014, 136: 13925-13931

17 Shang X, Yan KL, Rao Y, et al. In situ cathodic activation of Vincorporated $\mathrm{Ni}_{x} \mathrm{~S}_{y}$ nanowires for enhanced hydrogen evolution. Nanoscale, 2017, 9: 12353-12363

18 Ambrosi A, Pumera M. Templated electrochemical fabrication of hollow molybdenum sulfide microstructures and nanostructures with catalytic properties for hydrogen production. ACS Catal, 2016, 6: 3985-3993

19 Zhang $\mathrm{Y}$, Liu $\mathrm{Y}$, Ma $\mathrm{M}$, et al. A Mn-doped $\mathrm{Ni}_{2} \mathrm{P}$ nanosheet array: an efficient and durable hydrogen evolution reaction electrocatalyst in alkaline media. Chem Commun, 2017, 53: 11048-11051

20 Shang X, Hu WH, Li X, et al. Oriented stacking along vertical (002) planes of $\mathrm{MoS}_{2}$ : a novel assembling style to enhance activity for hydrogen evolution. Electrochim Acta, 2017, 224: 25-31

21 Liu T, Ma X, Liu D, et al. Mn doping of CoP nanosheets array: an efficient electrocatalyst for hydrogen evolution reaction with enhanced activity at all pH values. ACS Catal, 2017, 7: 98-102

22 Yu J, Cheng G, Luo W. Hierarchical NiFeP microflowers directly grown on $\mathrm{Ni}$ foam for efficient electrocatalytic oxygen evolution. J Mater Chem A, 2017, 5: 11229-11235

23 Han GQ, Li X, Xue J, et al. Electrodeposited hybrid Ni-P/MoS film as efficient electrocatalyst for hydrogen evolution in alkaline media. Int J Hydrogen Energy, 2017, 42: 2952-2960

24 Tian L, Yan X, Chen X. Electrochemical activity of iron phosphide nanoparticles in hydrogen evolution reaction. ACS Catal, 2016, 6: 5441-5448

25 Mendoza-Garcia A, Su D, Sun S. Sea urchin-like cobalt-iron phosphide as an active catalyst for oxygen evolution reaction. Nanoscale, 2016, 8: 3244-3247

26 Fan X, Wang X, Yuan W, et al. Diethylenetriamine-mediated selfassembly of three-dimensional hierarchical nanoporous CoP nanoflowers/pristine graphene interconnected networks as efficient electrocatalysts toward hydrogen evolution. Sustain Energy Fuels, 2017, 1: 2172-2180

27 Li P, Zeng HC. Advanced oxygen evolution catalysis by bimetallic $\mathrm{Ni}-\mathrm{Fe}$ phosphide nanoparticles encapsulated in nitrogen, phosphorus, and sulphur tri-doped porous carbon. Chem Commun, 2017, 53: 6025-6028

28 Liu Z, Wang Y, Chen R, et al. Quaternary bimetallic phosphosulphide nanosheets derived from prussian blue analogues: Origin of the ultra-high activity for oxygen evolution. J Power Sources, 2018, 403: 90-96

29 Hao J, Yang W, Zhang Z, et al. Metal-organic frameworks derived
$\mathrm{Co}_{x} \mathrm{Fe}_{1-x} \mathrm{P}$ nanocubes for electrochemical hydrogen evolution. Nanoscale, 2015, 7: 11055-11062

30 Wang $\mathrm{AL}$, Lin $\mathrm{J}, \mathrm{Xu} \mathrm{H}$, et al. $\mathrm{Ni}_{2} \mathrm{P}-\mathrm{CoP}$ hybrid nanosheet arrays supported on carbon cloth as an efficient flexible cathode for hydrogen evolution. J Mater Chem A, 2016, 4: 16992-16999

31 Fang Z, Peng L, Qian Y, et al. Dual tuning of Ni-Co-A (A = P, Se, $\mathrm{O})$ nanosheets by anion substitution and holey engineering for efficient hydrogen evolution. J Am Chem Soc, 2018, 140: 52415247

32 Wang P, Pu Z, Li Y, et al. Iron-doped nickel phosphide nanosheet arrays: An efficient bifunctional electrocatalyst for water splitting. ACS Appl Mater Interfaces, 2017, 9: 26001-26007

33 Cabán-Acevedo M, Stone ML, Schmidt JR, et al. Efficient hydrogen evolution catalysis using ternary pyrite-type cobalt phosphosulphide. Nat Mater, 2015, 14: 1245-1251

34 Yan KL, Shang X, Zhang LM, et al. Boosting electrocatalytic activity of binary Ag-Fe-doped $\mathrm{Co}_{2} \mathrm{P}$ nanospheres as bifunctional electrocatalysts for overall water splitting. Electrochim Acta, 2017, 249: $16-25$

35 Zhang L, Chang C, Hsu CW, et al. Hollow nanocubes composed of well-dispersed mixed metal-rich phosphides in $\mathrm{N}$-doped carbon as highly efficient and durable electrocatalysts for the oxygen evolution reaction at high current densities. J Mater Chem A, 2017, 5: 19656-19663

36 Han L, Yu T, Lei W, et al. Nitrogen-doped carbon nanocones encapsulating with nickel-cobalt mixed phosphides for enhanced hydrogen evolution reaction. J Mater Chem A, 2017, 5: 1656816572

37 Yu Y, Peng Z, Asif M, et al. FeP nanocrystals embedded in Ndoped carbon nanosheets for efficient electrocatalytic hydrogen generation over a broad $\mathrm{pH}$ range. ACS Sustain Chem Eng, 2018, 6: 11587-11594

38 Gao WK, Lin JH, Wang K, et al. Controllable phosphorsulfurization of uniform binary Ni-Fe nanocubes for enhanced water oxidation. Mater Lett, 2018, 229: 248-251

$39 \mathrm{Wu} \mathrm{X}$, Shao $\mathrm{M}, \mathrm{Wu} \mathrm{C}$, et al. Low defect $\mathrm{FeFe}(\mathrm{CN})_{6}$ framework as stable host material for high performance Li-ion batteries. ACS Appl Mater Interfaces, 2016, 8: 23706-23712

40 Feng Y, Wei J, Ding Y. Mesoporous $\mathrm{Mn}_{1.8} \mathrm{Fe}_{1.2} \mathrm{O}_{4}$ nanocubes as robust catalysts for water oxidation. J Catal, 2016, 339: 186-194

41 Kumar A, Bhattacharyya S. Porous NiFe-oxide nanocubes as bifunctional electrocatalysts for efficient water-splitting. ACS Appl Mater Interfaces, 2017, 9: 41906-41915

$42 \mathrm{Pu}$ Z, Liu Q, Asiri AM, et al. Tungsten phosphide nanorod arrays directly grown on carbon cloth: a highly efficient and stable hydrogen evolution cathode at all $\mathrm{pH}$ values. ACS Appl Mater Interfaces, 2014, 6: 21874-21879

43 Nai J, Lu Y, Yu L, et al. Formation of Ni-Fe mixed diselenide nanocages as a superior oxygen evolution electrocatalyst. Adv Mater, 2017, 29: 1703870

44 Gao WK, Qin JF, Wang K, et al. Facile synthesis of Fe-doped $\mathrm{Co}_{9} \mathrm{~S}_{8}$ nano-microspheres grown on nickel foam for efficient oxygen evolution reaction. Appl Surf Sci, 2018, 454: 46-53

45 Li M, Liu X, Xiong Y, et al. Facile synthesis of various highly dispersive CoP nanocrystal embedded carbon matrices as efficient electrocatalysts for the hydrogen evolution reaction. J Mater Chem A, 2015, 3: 4255-4265

46 Song B, Li K, Yin Y, et al. Tuning mixed nickel iron phosphosulfide nanosheet electrocatalysts for enhanced hydrogen and oxygen evolution. ACS Catal, 2017, 7: 8549-8557 
47 Ray C, Lee SC, Jin B, et al. Stacked porous iron-doped nickel cobalt phosphide nanoparticle: An efficient and stable water splitting electrocatalyst. ACS Sustain Chem Eng, 2018, 6: 6146-6156

48 Zhao ZW, Wen T, Liang K, et al. Carbon-coated $\mathrm{Fe}_{3} \mathrm{O}_{4} / \mathrm{VO}_{x}$ hollow microboxes derived from metal-organic frameworks as a highperformance anode material for lithium-ion batteries. ACS Appl Mater Interfaces, 2017, 9: 3757-3765

49 Bai J, Xi B, Mao H, et al. One-step construction of N,P-codoped porous carbon sheets/CoP hybrids with enhanced lithium and potassium storage. Adv Mater, 2018, 30: 1802310

50 Yan KL, Chi JQ, Xie JY, et al. Mesoporous Ag-doped $\mathrm{Co}_{3} \mathrm{O}_{4}$ nanowire arrays supported on FTO as efficient electrocatalysts for oxygen evolution reaction in acidic media. Renew Energy, 2018, 119: 54-61

51 Liao H, Sun Y, Dai C, et al. An electron deficiency strategy for enhancing hydrogen evolution on CoP nano-electrocatalysts. Nano Energy, 2018, 50: 273-280

52 Feng JX, Wu JQ, Tong YX, et al. Efficient hydrogen evolution on $\mathrm{Cu}$ nanodots-decorated $\mathrm{Ni}_{3} \mathrm{~S}_{2}$ nanotubes by optimizing atomic hydrogen adsorption and desorption. J Am Chem Soc, 2018, 140: 610-617

53 Hu E, Feng Y, Nai J, et al. Construction of hierarchical Ni-Co-P hollow nanobricks with oriented nanosheets for efficient overall water splitting. Energy Environ Sci, 2018, 11: 872-880

54 Chi JQ, Gao WK, Zhang LM, et al. Induced phosphorization-derived well-dispersed molybdenum phosphide nanoparticles encapsulated in hollow $\mathrm{N}$-doped carbon nanospheres for efficient hydrogen evolution. ACS Sustain Chem Eng, 2018, 6: 7676-7686

55 Ha DH, Han B, Risch M, et al. Activity and stability of cobalt phosphides for hydrogen evolution upon water splitting. Nano Energy, 2016, 29: 37-45

56 Zhang X, Li C, Si T, et al. FeNi cubic cage@N-doped carbon coupled with $\mathrm{N}$-doped graphene toward efficient electrochemical water oxidation. ACS Sustain Chem Eng, 2018, 6: 8266-8273

57 Chi JQ, Gao WK, Lin JH, et al. Porous core-shell N-doped $\mathrm{Mo}_{2} \mathrm{C} @ \mathrm{C}$ nanospheres derived from inorganic-organic hybrid precursors for highly efficient hydrogen evolution. J Catal, 2018, 360: 9-19

58 Sun $\mathrm{H}, \mathrm{Xu} \mathrm{X}$, Yan $\mathrm{Z}$, et al. Porous multishelled $\mathrm{Ni}_{2} \mathrm{P}$ hollow microspheres as an active electrocatalyst for hydrogen and oxygen evolution. Chem Mater, 2017, 29: 8539-8547

Acknowledgements This work was supported by the Natural Science Foundation of Shandong Province (ZR2017MB059), the Major Program of Shandong Province Natural Science Foundation (ZR2018ZC0639), the National Natural Science Foundation of China (21776314), the Fundamental Research Funds for the Central Universities (18CX05016A), and the Postgraduate Innovation Project of China University of Petroleum (YCX2018074).

Author contributions All authors contributed to the discussion and preparation of the manuscript. The final version of the manuscript was approved by all authors.

Conflict of interest The authors declare no conflict of interest.

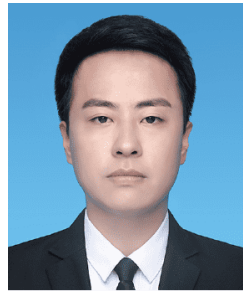

Wenkun Gao is currently a master candidate under the supervision of Professor Bin Dong in the State Key Laboratory of Heavy Oil Processing, China University of Petroleum (East China). He received his bachelor's degree majored in engineering from Jining University in 2015. His research interest focuses on electrochemical and photoelectrochemical water splitting.

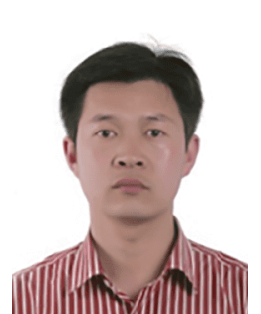

Bin Dong received $\mathrm{PhD}$ degree from Lanzhou University in 2008. He was a visiting scholar in Marquette University from 2014 to 2015. Now he is an associate professor in the College of Science, China University of Petroleum (East China). His research interests focus on the design and synthesis of functional materials for energy conversion and storage, such as electrocatalysis and photoelectrocatalysis for water splitting.

\section{原位构筑表面缺陷的碳掺杂型三元钴镍铁磷化物 纳米立方体用于高效全水分解}

高文坤 ${ }^{1}$, 杨敏 ${ }^{1}$, 迟京起 ${ }^{1}$, 张鍂宇 ${ }^{1}$, 谢静宜 ${ }^{1}$, 郭宝玉 ${ }^{1}$, 王否 ${ }^{2}$, 柴永明 ${ }^{1}$, 董斌

摘要 本文以三元金属钴-镍-铁普鲁士蓝结构纳米立方体 $\left(\mathrm{Co}_{0.9^{-}}\right.$ $\mathrm{Ni}_{0.9} \mathrm{Fe}_{1.2} \mathrm{NCs}$ ) 为前驱体, 通过简单气相磷化处理, 得到优化比例的 $\mathrm{P}-\mathrm{Co}_{0.9} \mathrm{Ni}_{0.9} \mathrm{Fe}_{1.2}$ 纳米立方体磷化物, 其具有高本征活性、导电性和 高缺陷密度的特点. SEM和TEM结果表明, 碳掺杂型 $\mathrm{P}-\mathrm{Co}_{0.9} \mathrm{Ni}_{0.9}{ }^{-}$ $\mathrm{Fe}_{1.2}$ 保持了纳米立方体的结构, 其粗粘的表面结构意味着丰富的缺 陷位，暴露更多真实活性位. 三元金属普鲁士蓝前驱体的磷化处理 不仅提供了碳掺杂，而且原位构筑了立方体表面缺陷位. 碳掺杂降 低了电荷传输的阻抗，优化了电子传输速率. 三元金属离子之间的 协同作用以及丰富的缺陷活性位有效提高了电催化的性能. $\mathrm{P}-\mathrm{Co}_{0.9} \mathrm{Ni}_{0.9} \mathrm{Fe}_{1.2}$ 拥有极其高的 HER和OER催化活性, 仅需要 $-200.7 \mathrm{mV}$ (HER) 和 $273.1 \mathrm{mV}$ (OER) 过电位就可以达到 $10 \mathrm{~mA} \mathrm{~cm}^{-2}$ 的电流密度. 其全水分解仅需 $1.52 \mathrm{~V}$ 就可以达到 $10 \mathrm{~mA} \mathrm{~cm}^{-2}$ 的电流 密度. 此外, 本文还对催化剂的稳定性进行了测试. 本工作为设计高 效过渡金属基双功能电解水催化剂提供了一种简便方法. 